\title{
Greenland precipitation trends in a long-term instrumental climate context (1890-2012): Evaluation of coastal and ice core records
}

\author{
SEBASTIAN H. MERNILD \\ Climate, Ocean, and Sea Ice Modeling Group, Computational Physics and Methods, \\ Los Alamos National Laboratory, New Mexico, USA, Glaciology and Climate Change \\ Laboratory, Center for Scientific Studies/Centro de Estudios Cientificos (CECs), \\ CHILE, $\underline{\text { mernild@ @ecs.cl }}$ \\ EDWARD HANNA \\ Department of Geography, University of Sheffield, Sheffield, UK \\ JOSEPH R. McCONNELL and MICHAEL SIGL \\ Desert Research Institute, Nevada, USA \\ ANDREW P. BECKERMAN \\ Department of Animal and Plant Sciences, University of Sheffield, Sheffield, UK \\ JOHN CAPPELEN \\ Danish Meteorological Institute, Copenhagen, DENMARK \\ JACOB C. YDE \\ Sogn og Fjordane University College, Sogndal, NORWAY \\ JEPPE K. MALMROS \\ Glaciology and Climate Change Laboratory, Center for Scientific Studies/Centro de \\ Estudios Cientificos (CECs), CHILE

\section{KONRAD STEFFEN} \\ Swiss Federal Research Institute WSL, Birmensdorf, Institute for Atmosphere and \\ Climate, Swiss Federal Institute of Technology, Zurich, and Architecture, Civil and \\ Environmental Engineering, Ecole Polytechnique Federal de Lausanne, Lausanne,
}

SWITZERLAND

Submitted to International Journal of Climatology, 4 December, 2013

Re-submitted 14 February, 2014

Corresponding author address:

Dr. Sebastian H. Mernild

Glaciology and Climate Change Laboratory

Center for Scientific Studies/Centro de Estudios Cientificos (CECs)

Av. Arturo Prat 514

5110466 Valdivia, CHILE

E-mail: smernild@gmail.com 


\begin{abstract}
Here, we present an analysis of monthly, seasonal, and annual long-term precipitation time-series compiled from coastal meteorological stations in Greenland and Greenland Ice Sheet (GrIS) ice cores (including three new ice core records from Act11D, Tunu2013, and Summit2010). The dataset covers the period from 1890 to 2012, a period of climate warming. For approximately the first decade of the new millennium (2001-2012) minimum and maximum mean annual precipitation conditions are found in Northeast Greenland (Tunu2013 c. $120 \mathrm{~mm}$ water equivalent (w.e.) $\mathrm{yr}^{-1}$ ) and South Greenland (Ikerasassuaq: c. 2,300 mm w.e. $\mathrm{yr}^{-1}$ ), respectively. The coastal meteorological stations showed on average increasing trends for 18902012 (3.5 mm w.e. $\mathrm{yr}^{-2}$ ) and 1961-2012 (1.3 mm w.e. $\mathrm{yr}^{-2}$ ). Years with high coastal annual precipitation also had a: 1) significant high number of precipitation days $\left(r^{2}=\right.$ $0.59)$; and 2) high precipitation intensity measured as 24-hour precipitation $\left(r^{2}=\right.$ 0.54). For the GrIS the precipitation estimated from ice cores increased on average by $0.1 \mathrm{~mm}$ w.e. $\mathrm{yr}^{-2}$ (1890-2000), showing an anti-phase variability in precipitation trends between the GrIS and the coastal regions. Around 1960 a major shift occurred in the precipitation pattern towards wetter precipitation conditions for coastal Greenland, while drier conditions became more prevalent on the GrIS. Differences in precipitation trends indicate a heterogeneous spatial distribution of precipitation in Greenland. An Empirical Orthogonal Function analysis reveals a spatio-temporal cycle of precipitation that is linked instantaneously to the North Atlantic Oscillation and the Atlantic Multidecadal Oscillation and with an approximately six years lag time response to the Greenland Blocking Index.
\end{abstract}

Keywords: climate; Greenland; ice core; observations; precipitation; weather stations 


\section{Introduction}

During the last decade attention has been on climate change and its present and potential future impact on the mass balances of the Greenland Ice Sheet (GrIS) and peripheral glaciers and ice caps (GIC) (e.g., Steffen and Box 2001; Hanna et al. 2005, 2006; 2008, 2011; 2013a, 2013b; Box et al. 2006; Fettweis et al. 2008; Bales et al., 2009; Ettema et al. 2009; van den Broeke et al 2009; Radić and Hock 2011; Mernild et al. 2010a, 2011a, 2011b, 2013a, 2013b; Marzeion et al. 2012; IPCC 2013: Chapters 4 and 13), and freshwater (river) runoff from Greenlandic glacier-covered catchments (e.g., Mernild et al. 2010b, 2011c; Mernild and Liston 2012; Rennermalm et al. 2012; Mikkelsen et al. 2013). Mass-balance changes are the sum of surface accumulation (precipitation), surface ablation (evaporation, sublimation, and runoff), and wastage processes (calving), and are to a large extent influenced by changes in Greenlandic climate and ocean temperatures (e.g., Straneo et al. 2010, 2013; Hanna et al. 2009, 2013c).

An improved and updated understanding of precipitation conditions in Greenland is relevant not only to climatologists but also to glaciologists, hydrologists, ecologists and the wider population due to e.g., the potential for hydropower production in Greenland. Therefore, the motivation for this Greenland precipitation analysis is to include both the coastal zone (the land area between the ocean and GrIS, including several thousand GIC) and the GrIS for climatological normal periods, to enlarge our knowledge, which will contain an expanded update of earlier comprehensive Greenland climate and precipitation studies (1958-2005) (Yang et al. 1999; Steffen and Box 2001; Hanna et al. 2006, Bales et al. 2009). This study is timely given the recent rapid changes in Greenland climatology (Hanna et al. 2012, 2013a; Mernild et al. 2013c) and GrIS and GIC mass balances (e.g., Box et al. 2012; Liston and Mernild 2012, Hanna et al. 2013b) that have occurred over the past few decades.

Here, we present long-term monthly, seasonal, and annual precipitation time series from near-coastal meteorological stations in Greenland (1890-2012) and GrIS ice cores (1890-2011). We examine climatological normal periods and shorter recent periods in order to provide evidence of climate change and variability in precipitation patterns. Also, we analyze the coastal precipitation intensity - expressed as the highest 24-hour precipitation - and the number of precipitation days in relation to the precipitation sum, and the occurrence and trends of driest and wettest conditions on 
monthly, seasonal, and annual time-scales. Finally, we employ an Empirical Orthogonal Function (EOF) analysis to evaluate the patterns of temporal and spatial precipitation variations, and combine these with cross-correlations to relate the Greenland precipitation patterns to atmospheric circulation indices: the North Atlantic Oscillation (NAO), the Atlantic Multidecadal Oscillation (AMO), and the Greenland Blocking Index (GBI).

This paper follows the analytical structure of Hanna et al. (2012b), where long-term near-coastal surface air temperature records were analyzed on monthly, seasonal, and annual time-scales. To keep the analyses similar, our precipitation datasets were analyzed on a seasonal scale using standard three-month meteorological seasons: December through February (DJF: winter), March through May (MAM: spring), June through August (JJA: summer), September through November (SON: autumn).

\section{Precipitation dataset and analysis}

\subsection{Near-coastal precipitation records}

Coastal precipitation data were measured at fourteen Greenland synoptic weather stations operated by Danish Meteorological Institute (DMI) (Cappelen 2013a, 2013b) (Figure 1). Technical weather station details, including details of locations and running time periods, for the stations used herein are illustrated in Table 1. The coastal precipitation data have been quality controlled (initially subject to visual examination) and homogenized using the standard normal homogeneity test (Steffensen et al. 1993; Steffensen 1996), and compared with neighboring station records where data are available (Cappelen 2013a). Where the homogeneity test was not conducted by DMI, it was specifically done for this study (this was the case for the stations Nuuk, Ittoqqortoormiit, and Tasiilaq). Periodic gaps in the coastal dataset were filled using linear correlation against the nearest coastal station. Bales et al. (2009) stated that this method provides the best available estimate for gap filling, even though the stations might be several hundreds of kilometers apart. Five of the coastal station sites Upernavik, Ilulissat, Nuuk, Ivittuut, and Tasiilaq (Figure 1) all have observed precipitation records extending back before 1900, giving a reasonable longterm distribution of precipitation patterns in the coastal zone from Northwest Greenland (Upernavik) going south to Southeast Greenland (Tasiilaq). The other station records extend back to around 1961, except for Kangerlussuaq (1976-2012). 
Coastal precipitation was measured using the manual Danish Hellmann-type gauges (200 $\mathrm{cm}^{2}$ opening) placed with their orifices $c .2 .5 \mathrm{~m}$ above the ground surface and equipped with a Nipher shield to minimize undercatch due to drifting snow (Allerup et al. 2000), or the automatic Geonor and Pluvio gauges (having the same opening area, distance above the ground, and shield as the Hellmann gauges). The observed precipitation dataset was bias-corrected following Allerup et al. (1998, 2000) due to systematic errors such as wind-induced undercatch (because of wind field deformation and turbulence from the measurement instrument) and wetting losses (water subject to evaporation from the surface of the inside walls of the precipitation gauge after a precipitation event and water retained on the walls of the gauge and its containers after its emptying (e.g., Goodison et al. 1989; Metcalfe et al. 1994)). The mean bias correction multiplier for undercaught precipitation was $1.47 \pm$ 0.12 (where \pm henceforth equals one standard deviation) for all fourteen stations (Table 1), ranging from 1.48-1.74 in the northern part of coastal Greenland to 1.271.56 in the southern part. These correction intervals correspond to results from Yang et al. (1999), who reported total annual gauge bias corrections of 1.50-1.75 in the northern part and 1.20-1.40 in the southern part for the Hellmann gauge-measured precipitation. In their analysis, Yang et al. (1999) included wind-induced undercatch, wetting losses, and trace amounts. The latter is a measurement of precipitation of less than $0.1 \mathrm{~mm}$, which is below the resolution of the gauge measurement. The bias correction was highest where the percentage of snow in total annual precipitation was greatest, varying from $c .70-80 \%$ in the northern part of Greenland to $c .30-40 \%$ in the southern part. This regional disparity corresponds with progressively higher temperatures from north to south. This has also been confirmed by e.g., Yang et al. (1999) and Bales et al. (2009). Henceforth, bias corrected precipitation will be referred to as precipitation.

We calculate mean annual sums of coastal precipitation from seven stations asterisked (*) in Table 1 to construct a coastal composite Greenland precipitation (CGP1) time series from 1961 to 2012 (shown as an anomaly in Figure 2a): Out of the seven station time series, 351 of 364 (96\%) annual precipitation values were present and used for the CGP1 time series. Where data were missing (4\%) the mean annual CGP1 sums were calculated only based on available data. In addition, we construct a composite coastal Greenland precipitation (CGP2) time series from 1900 to 2012 based on sums from the only two long-term coastal stations covering the entire period 
asterisked (**) in Table 1: Nuuk (1890-2012) and Tasiilaq (1898-2012) (Figure 2a). For the CGP2 1900-2012 time series $84 \%$ of the data were present and used for the years where mean annual precipitation data were present for both Nuuk and Tasiilaq. CGP2 has the advantage of illustrating the coastal composite precipitation changes for parts of the southern half of Greenland since 1898, through two periods during the 1930s-1940s and 1990s-2012, where regional warming is acknowledged (e.g., Chylek et al. 2006, Hanna et al. 2012). However, quite often precipitation trends are opposite in southeast and southwest Greenland and have different climatic forcing functions. Precipitation in southeast Greenland is generally affected by the cyclonicity between Iceland and Greenland, whereas precipitation in southwest Greenland is often dominated by low pressures forming in the Labrador Sea (e.g. Hanna et al. 2006).

\subsection{Ice core estimated precipitation records}

Precipitation from the GrIS was estimated from annual layer water-equivalent thicknesses from 15 ice cores (Figure 1 and Table 2). These ice-core time-series provide a spatial GrIS net solid precipitation (i.e. net accumulation) distribution from 1890-2010 for the Tunu2013 and Act11d ice cores, 1890-2009 (Summit2010), 18902003 (Act2d and Act3), 1890-2002 (McBales, D4, and D5), 1890-2001 (NEEM2008-S3), 1890-1998 (D1, D2, and D3), 1890-1995 (GITS), and 1890-1994 (HumbMain and Nasau). This method for determining GrIS net solid precipitation does take into account the effects of evaporation and sublimation and would therefore potentially underestimate the actual annual total precipitation. Evaporation is almost negligible at the interior of the GrIS due to daily near-surface air temperatures and

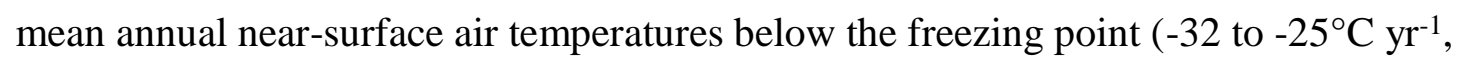
1950-2011) (McGrath et al. 2013), where sublimation is likely to be the primary cause of ablation. Surface mass balance simulations indicate that sublimation loss constitutes about $8 \%$ (1960-2010) of the annual GrIS precipitation (Mernild et al. 2008a; Mernild and Liston 2012). Therefore, to compensate for the sublimation and evaporation loss annual GrIS net precipitation was adjusted (in line with previous work by Bales et al. 2009) by adding $8 \%$. Therefore, the GrIS ice-core corrected net solid precipitation will henceforth be referred to as precipitation.

From 1890 to $1994100 \%$ coverage of annual ice core estimated precipitation values were present for all 15 ice core time series. From 1995 to 2000, 67 of 90 (74 
$\%$ ) annual precipitation values were present and used, whereas from 2001 to 2010 only 42 of $150(28 \%)$ were available. This decreasing amount of available ice core data through time is in contrast to the increasing amount of data from coastal weather stations, where the majority of observations are available for 1961 to 2012. Based on the ice-core estimated precipitation dataset (from all 15 ice cores) we present a composite GrIS ice core precipitation (CGIC) time-series from 1890 to 2000 (shown as an anomaly in Figure 2a), however CGIC time-series might be biased after 1995 due to incomplete ice core time-series. Due to low coverage of available ice core data, the latest decade (2001-2010) was excluded from the CGIC time-series.

Ice cores were collected from higher elevation (> $2000 \mathrm{~m}$ ) sites widely distributed around the GrIS (Figure 1). Details on the collection and measurement techniques used to develop many of the ice core accumulation records have previously been presented (e.g., Bales et al. 2009; Hanna et al. 2006, 2011). Hence, here we focus on the development of three new ice core records: Act11D, Tunu2013, and Summit2010. All three ice cores were collected without drilling fluid using an electromechanical drill. The $\sim 1 \mathrm{~m}$ long cores were returned frozen to the laboratory (in Reno, Nevada), where they were cut into longitudinal samples with cross sections $\sim 0.032$ by $\sim 0.032 \mathrm{~m}$. The longitudinal samples were analyzed for a broad range of $\sim 35$ elements, chemical species, and water isotopes using a unique continuous ice core melter system (McConnell et al. 2002, 2007). While nearly all parameters show distinct annual cycles, we primarily used non-sea-salt sulfur, calcium, sodium, black carbon, and deuterium to count annual layers. Well-known, dated volcanic horizons were used to confirm the annual layer counts (Sigl et al. 2013). Uncertainty in the annual dating is estimated to be $<2$ year for the Tunu2013 and Summit2010 records, which were collected in the dry snow zone of the GrIS. Act11d was collected in the percolation zone, where meltwater forming at the surface percolates into the snowpack before refreezing, thereby mixing the preserved chemical record. Percolation at the Act11d site generally is limited to much less than the thickness of the annual snow layer so perturbation of the record is limited. We estimate the annual dating uncertainty at Act $11 \mathrm{~d}$ as well to be $<2$ years. Annual net accumulation in water equivalent was determined from the difference in depth between two annual markers after converting the chemical records from snow depth to water equivalent depth. Previous studies using continuous measurements of closely spaced ice cores suggest 
that due to surface undulations on the ice sheet the uncertainty in ice-core-derived annual accumulation measurements is $\sim 30 \mathrm{~mm}$ w.e. $\mathrm{yr}^{-1}$ (McConnell et al. 2000).

\subsection{Statistical calculations}

We applied standard descriptive statistics such as mean values, standard deviation and extreme (minimum and maximum) values. In addition, linear regression analysis was used to evaluate evidence of changes and trends for the various climatological normal periods overlapping by 10-year intervals (e.g., 1961-1990, 1971-2000, etc.). Shorter recent periods of interest, e.g., 1991-2012 and 2001-2012, were also included in these calculations. To test for possible relations and trends, all correlations labeled as 'significant' are at or above the $95 \%$ confidence level $(p<$ 0.05 ; where $p$ is level of significance, indicating that there is less than $5 \%$ probability that such a correlation between the two time series was produced by chance). Such calculations are based on the null hypothesis. Also, we use a 10-year running average (five years back in time and four years forward in time) analysis to illustrate the general variability and periods of years with low/high sums of precipitation.

Further, we analysed the spatio-temporal patterns of precipitation using the Empirical Orthogonal Function (EOF) method. EOF analysis treats the time by spatial location precipitation as a matrix and orders these data using singular value decomposition to return major axes of variation in precipitation of the same length as the precipitation time series. The eigenvectors associated with such an analysis are linked to the spatial locations and reveal relationships between the sites and the major axes. All data were centered and scaled before analysis.

We then used cross-correlation functions to reveal the relationship between the summarizing EOF functions and three large-scale climatic indices: the North Atlantic Oscillation obtained from Hurrell and van Loon (1997;

http://gcmd.nasa.gov/records/GCMD_NCAR_NAO.html) (i.e. the mean sea-level pressure difference between the Azores and Iceland), the Atlantic Multidecadal Oscillation updated from Kaplan et al. (1998; http://www.esrl.noaa.gov/psd/data/timeseries/AMO/) (i.e. the expression of fluctuating mean sea-surface temperature (SST) in the North Atlantic region, illustrating alternating multi-decadal periods of cool and warm SST anomalies throughout the North Atlantic Ocean (Schlesinger and Ramankutty 1994, Kerr 2000, Knudsen et al. 2011)), and the Greenland Blocking Index (obtained from Fang 2004, 
Hanna et al. 2013a, 2013c), which is defined as the normalized values of the $500 \mathrm{hPa}$ mean geopotential height over the GBI domain $60^{\circ} \mathrm{N}-80^{\circ} \mathrm{N}$ and $20^{\circ} \mathrm{W}-80^{\circ} \mathrm{W}$. The cross correlation function reveals contemporary or lagged correlations between the indices, helping to add insight into the forces driving the spatio-temporal precipitation patterns on Greenland. We estimated the cross correlations for each index as the $\mathrm{x}$ variable and the EOFs as y-variables, so that positive correlations are interpreted as the EOF summary of precipitation lagging behind the indices.

\section{Results and discussions}

\subsection{Annual precipitation trends}

Mean annual coastal precipitation for the most recent 2001-2012 period ranged from $302 \pm 94 \mathrm{~mm}$ water equivalent (w.e.) $\mathrm{yr}^{-1}$ at Danmarkshavn in Northeast Greenland to 2,283 $\pm 576 \mathrm{~mm}$ w.e. $\mathrm{yr}^{-1}$ at Ikerasassuaq, on the east coast in the far south (Table 3a). On the GrIS mean annual precipitation for this period ranged from $123 \pm 22 \mathrm{~mm}$ w.e. $\mathrm{yr}^{-1}$ at Tunu2013 (in the northeast) to $378 \pm 64 \mathrm{~mm}$ w.e. $\mathrm{yr}^{-1}$ at Act11d (in the southwest close to Kangerlussuaq) (Table 4). At Ikerasassuaq, the precipitation pattern is highly affected by synoptic cyclone passages passing close to Iceland, which typically set up a prevailing easterly airflow towards the southeast coast of Greenland, with orographic enhancement of resulting precipitation (e.g. Hanna et al. 2006, Bales et al. 2009). In general, the mean annual coastal precipitation decreased with increasing latitude (a similar trend occurred for the GrIS) and with increasing distance from the coast inland towards the ice-sheet margin. As an example, in both West Greenland between Sisimiut (at the coast) and Kangerlussuaq (c. $130 \mathrm{~km}$ east of Sisimiut and c. $25 \mathrm{~km}$ from the ice-sheet margin) and South Greenland between Qaqortoq (at the coast) and Narsarsuaq (c. $60 \mathrm{~km}$ northeast of Qaqortoq and c. $30 \mathrm{~km}$ from the ice-sheet margin), the mean annual precipitation sum

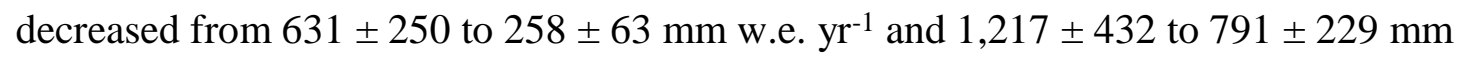
w.e. $\mathrm{yr}^{-1}$ (2001-2012), respectively. Similar coastal-to-inland precipitation trends also existed for other periods 1961-1990 to 1991-2012 for which data are available (Table 3a), and are likely explained by prevailing wind circulation (e.g., katabatic winds draining downslope from the ice-sheet interior), distance from the oceanic moisture source and the orographic effect of near-coastal mountains - the latter being especially important in Southeast Greenland. We would therefore expect similar coastal-to-inland precipitation trends elsewhere along the Greenland coast. This is in 
contrast to previous work by Bales et al. (2009), who for short distances near the coast, due to orographic enhancements (and the use of high spatial resolution radar profiles), noted an increase in precipitation towards inland areas in Southeast Greenland.

The mean annual coastal precipitation sums for the most recent 2001-2012 period for the only two long-term precipitation time series Nuuk and Tasiilaq (19012012) yield the highest mean precipitation sum of 1,369 \pm 339 for Nuuk and one of the highest mean precipitation sums of $1,257 \pm 232 \mathrm{~mm}$ w.e. $\mathrm{yr}^{-1}$ for Tasiilaq, with both locations significantly $(p<0.01)$ above the mean annual precipitation sums of the warm 1930s-1940s depicted by the 1921-1950 and 1931-1960 climatological normal periods (Table 3a). On an annual timescale, Aasiaat, Sisimiut, and Qaqortoq recorded their maximum annual precipitations in 2012, and Nuuk recorded its maximum annual precipitation in 2005 (highlighted in bold in Table 7). This is in contrast to the annual precipitation trends on the GrIS where no annual maximum or minimum precipitation occurred for the most recent decade (Table 8). Further, the three long-term ice core time series: Summit2010, Tunu2013, and Act11d showed no significant trends or differences in precipitation sums between the most recent period and the sums of the warm 1930s-1940s (depicted by the 1921-1950 and 1931-1960 normal periods) (Table 4 and Figure 3a).

For the CGP2 time series (1900-2012) (Figure 2a), based on a 10-year running mean, below-average coastal precipitation occurred continuously until the late $1950 \mathrm{~s}$, and thereafter continuously above average. The mean difference was $c$. $500 \mathrm{~mm}$ w.e. $\mathrm{yr}^{-1}$ in the running average, with a maximum running average difference more than $650 \mathrm{~mm}$ w.e. $\mathrm{yr}^{-1}$ (for annual precipitation values the difference between extreme dry and wet conditions was above 1,160 mm w.e. $\mathrm{yr}^{-1}$ ), and almost matching - in anti-phase (from 1925-1995; $r^{2}=0.58$ ) - the running mean variability in the AMO index (Figure 2a). The rapid 1950s phase change indicates that major changes in precipitation patterns over Greenland may occur even over short time periods of approximately ten years. The antiphase CGP2-AMO relation shown here is similar to that depicted in Mernild et al. (2012) between the Tasiilaq annual precipitation sum and the AMO index time series, while the Tasiilaq annual air temperature time series overall was in phase with the AMO index time series. As well as for Nuuk, the annual precipitation sum was almost matching $\left(r^{2}=0.45\right.$, square of the linear correlation coefficient; $p<0.01$ ) - in anti-phase (from 1925-1995) - the running mean variability 
in the AMO index. For the annual CGP1 time series (1961-2012) only minor variations (a maximum difference in running average of $115 \mathrm{~mm} \mathrm{w.e.} \mathrm{yr}^{-1}$ and in annual values of $615 \mathrm{~mm}$ w.e. $\mathrm{yr}^{-1}$ ) occurred during periods with negative (19651995) and positive (1996-2012) AMO index.

For the CGIC time series (1890-2000) (Figure 2a), based on a 10-year running mean, the average GrIS precipitation almost followed the running mean variability in the AMO index (before the late-1920s the CGIC and AMO curves were both below average, during the period from the 1920s to the mid-1960s the curves were above average, and on average below average from the mid-1960s to the mid-1990s) illustrating a GrIS ice core estimated precipitation regime in anti-phase with the coastal precipitation regime. On the regional scale, a division of the GrIS ice core time series into three regions (north, centre and south; Figure 1) showed that the same overall patterns occurred. However, a gradient in mean values was shown from the northern region of $221 \pm 120 \mathrm{~mm}^{\mathrm{w}}$.e. $\mathrm{yr}^{-1}$ to the southern region of $588 \pm 229 \mathrm{~mm}$ w.e. $\mathrm{yr}^{-1}(1890-2000)$ (Figure 3b).

At the individual coastal station scale for the most recent 2001-2012 period, the greatest overall positive and negative trends in observed annual precipitation occurred for Sisimiut and Tasiilaq of $48.5 \mathrm{~mm}$ w.e. $\mathrm{yr}^{-2}$ (and a percentage change of $130 \%$ of the initial precipitation value) and $-53.9 \mathrm{~mm} \mathrm{w.e.} \mathrm{yr}^{-2}(-40 \%)$, respectively (both significant; $p<0.01$ ) (Table 5a). The spatial distribution of the precipitation trends for all the coastal meteorological stations is heterogeneous, depicting both increasing and decreasing trends. This is evident even for relatively short distances between the stations, probably due to a combination of both local and regional weather conditions. For example, the Sisimiut precipitation trend (2001-2012; see above) shows a significant increase but for the same time there was no significant trend at Kangerlussuaq, located $130 \mathrm{~km}$ inland. For the same time period, Narsarsuaq and Qaqortoq had insignificant trends, respectively. It is also noteworthy that for none of the normal periods did all coastal stations simultaneously record either positive or negative precipitation trends; similar heterogeneous trend patterns occurred for the GrIS ice core estimated precipitation time series, including the three ice cores: Summit2010, Tunu2013, and Act11d covering the latest decade (Table 6). This variability illustrates complex temporal and spatial precipitation patterns in Greenland. However, for the CGP1 (1961-2012), CGP2 (1900-2012), and CGIC (1890-2000) anomaly time series the annual precipitation increased on average by 1.3 
$\mathrm{mm}$ w.e. $\mathrm{yr}^{-2}$ (insignificant), $3.5 \mathrm{~mm}$ w.e. $\mathrm{yr}^{-2}$ (significant, $p<0.01$ ), and $0.1 \mathrm{~mm}$ w.e. $\mathrm{yr}^{-2}$ (insignificant) (Figures 2a and 3), respectively. These overall upward trends may indicate that the amount of precipitation across Greenland is increasing in a warming climate. This is in accordance with rising temperatures documented in previous published Greenland climatological analyses such as Hanna et al. (2012).

\subsection{Annual temporal and spatial precipitation conditions}

The complex, spatially variable Greenland precipitation trends are captured effectively by the EOF analysis. The first two modes EOF1 (the uniform patterns) and EOF2 (the spatially segregated patterns), represent $46 \%$ and $12 \%$, respectively, of the squared covariance. They reveal two potential patterns (Figures $4 \mathrm{a}$ and $4 \mathrm{~b}$ ), where only EOF1 is statistically significant. However, we report the patterns for both EOF modes for comparative purposes.

Visible via the smoothing line (10-year running mean) in Figure 4a, EOF1 was positive between 1900-1930 and 1960-1980 and negative between 1930-1960, and 1980-2012. Figure 5 presents the eigenvectors associated with each EOF, capturing specific relationships with the EOFs for each location. The overwhelming negative correlation values for EOF1 (Figure 5a) indicate a negative correlation with patterns of precipitation and EOF1 for almost all sites (except for three locations which were positively correlated with EOF1). This suggests variability in Greenland precipitation conditions over time (see Figure 4a), and the most recently (since 1980) wetter conditions. The three locations with positive EOF1 values are Ikerasassuaq, Ittoqqortoormiit, and Danmarkshavn (Figure 5a), all located in coastal South and East Greenland. They stand out as possessing a different precipitation regime. We suggest that this EOF1 captures a spatially consistent signature by virtue of the overwhelmingly negative eigenvectors, though there are sites near zero (D1, Neem2008-S3, and Tunu2013) that join the three positive EOF1 values to generate a pattern in space and time for Greenland.

For EOF2 (Figures 4b, 4d, and 5b), a much more substantial separation between the interior and the coastal precipitation regimes are suggested. For example, 11 out of 15 ice core locations at the interior had a positive correlation with EOF2, while eight out of 14 station locations in the coastal zone had negative correlations with EOF2 (Figure 5b). As with EOF1, there are some exceptions, since a few ice 
cores seems to be more similar to the coastal precipitation regime, and a few coastal stations were more similar to the interior precipitation regime (Figures $5 \mathrm{a}$ and $5 \mathrm{~b}$ ).

Further insight into the drivers of the uniform patterns in EOF1 and spatially segregated patterns in EOF2 are revealed via cross correlations with the NAO index, AMO Index, and GBI (Figure 6). EOF1 (Figure 6a) is positively correlated $\left(r^{2}=0.20\right.$; significant) with NAO and negatively correlated (-0.28; significant) with AMO at lag 0 , and negatively correlation with the GBI (-0.31; significant) at lag 6 (i.e. a lagging time of approximately six years). This signal indicates that the general pattern of precipitation shown via EOF1 is linked to current NAO and AMO conditions, and responds inversely to GBI influences approximately six years later. The relationship between EOF2, capturing some stark spatial variation between coastal and ice-core patterns and the indices is illustrated in Figure 6b. The pattern captured in EOF2 is negatively correlated $\left(r^{2}=-0.40\right.$; significant $)$ with NAO at lag 0 , negatively correlated with AMO (-0.21; significant) at lag 9, and positively correlated with GBI (0.30; significant) at lag 7, suggesting a delayed response to both of the climate indices AMO and GBI. The physical mechanism seems not clear, unless this is some kind of response to long-term cycles in AMO and, possibly, GBI.

Overall for the annual analysis, the eigenvectors interpolated across longitudes and latitudes highlights the spatio-temporal pattern of precipitation across Greenland (Figures $4 \mathrm{c}$ and $4 \mathrm{~d}$ ). For EOF1 the signature of Greenland precipitation indicates three sections: one in northwest, southeast, and northeast Greenland with sites (Figure 4c), that all are near zero or positively correlated, and different from the conditions in the interior of the GrIS. This separation between northwest, southeast, and northeast could probably be due to the different climatic forcing functions for Greenland, where precipitation in the northeast may be dominated by changes in the sea-ice content, in the coastal southeast by a combination of synoptic cyclone passages near Iceland and orographic enhancement of precipitation, and in (south)west Greenland by low pressures forming in the Labrador Sea (e.g. Hanna et al. 2006). In the interior the signature indicates positively correlated conditions, suggesting that the variability in ice-core estimated precipitation may be influenced by the same overall climatic precipitation and topographical conditions. For EOF2 (Figure 4b), the spatially interpolated conditions seem however to have a less clear signature.

\subsection{Seasonal coastal precipitation trends}


On a seasonal timescale, for both winter and spring the mean coastal precipitation sums for the most recent period 2001-2012 were lowest for Kangerlussuaq and highest for Ikerasassuaq, whereas for both summer and autumn minima were recorded at Danmarkshavn and maximum at Ikerasassuaq (Tables 3be). Also for other periods, Ikerasassuaq had maximum seasonal precipitation sums for all four seasons (1991-2012, where data are available), while the minimum seasonal sums alternated between Danmarkshavn and Kangerlussuaq (1991-2012, and 19812012, where data are available). This probably reflects higher temperatures and a convective/Labrador Sea influence on Kangerlussuaq precipitation in summer. At Ikerasassuaq, the range in mean seasonal precipitation sum (2001-2012) varied from $553 \pm 289 \mathrm{~mm}$ w.e. in spring to $695 \pm 232 \mathrm{~mm}$ w.e. in summer (Table $3 \mathrm{~b}-\mathrm{e}$ ). For the minimum locations, the winter and spring mean (2001-2012) sums at Kangerlussuaq were $40 \pm 12$ and $44 \pm 30 \mathrm{~mm}$ w.e., respectively, and summer and autumn sums at Danmarkshavn were $51 \pm 33$ and $56 \pm 20 \mathrm{~mm}$ w.e., respectively. It is worth mentioning that for all four seasons the mean seasonal coastal precipitation sum decreased with increasing latitudes and along the two coastal-to-inland transects from Sisimiut to Kangerlussuaq and Qaqortoq to Narsarsuaq. These overall latitudinal and coastal-to-inland patterns are present not only for the most recent period, but also for the periods 1961-1990 and 1991-2012, where data are available (Table 3b-e).

Also, Nuuk (one of the two stations used in the CGP2 time series) yields for the most recent 2001-2012 period the highest mean precipitation sum for annual and all seasons, whereas for Tasiilaq the spring and winter seasons had the highest mean seasonal precipitation sums for the 1971-2000 climatological normal period, 19611990 for summer, and 1901-1930 for autumn (Table 3a-e). These differences highlight different prevailing precipitation patterns (and probably climatic forcing factors; Hanna et al. 2013a) for Nuuk and Tasiilaq. Also, regarding the record wettest and driest monthly and seasonal conditions for all stations, Kangerlussuaq, Narsarsuaq, Danmarkshavn, and Ikerasassuaq had record-high monthly and seasonal precipitation within the most recent period 2001-2012 (highlighted with bold in Table 10). This is in contrast to Qaqortoq, Ittoqqortoormiit, and Tasiilaq, where precipitation records rarely occurred during the last decade.

For the individual seasonal composite coastal Greenland anomaly precipitation time series CGP2 (1900-2012) (Figure 2c) the 10-year running average follows the overall annual trend (Figure 2a), where all seasons - except for a few years in summer 
and autumn - were below average up to the late 1950s, and thereafter above average. For all four seasonal anomaly time series a clear shift in the amount of precipitation from relatively dry to wet conditions occurred around 1960. The trend lines in Figure 2c indicate (1900-2012) that the greatest seasonal changes in precipitation sum occurred during winter time $\left(20.6 \mathrm{~mm}\right.$ w.e. decade $^{-2}$; significant $\left.\mathrm{p}<0.01\right)$, and smallest seasonal changes during autumn ( $2.0 \mathrm{~mm}$ w.e. decade ${ }^{-2}$; insignificant). On a shorter/more recent time frame (1961-2012), the CGP1 seasonal time series indicates increasing coastal seasonal precipitation sums for spring, autumn, and winter in the range of 4.4 to $6.0 \mathrm{~mm}$ w.e. decade ${ }^{-2}$ (all insignificant), and decreasing sums for summer time of $3.8 \mathrm{~mm}$ w.e. decade ${ }^{-2}$ (insignificant). For the specific location near Tasiilaq it is possible to compare precipitation changes with glacier mass-balance observations (from the only long-term observed mountain glacier in Greenland, the Mittivakkat Gletscher 1995/1996 to present (Figure 1); Knudsen and Hasholt 2008; Mernild et al. 2013b, 2013c). The glacier is located about $10 \mathrm{~km}$ west of the Tasiilaq meteorological station. The comparison supports that a clear negative trend occurred based on seasonal changes in autumn, winter and spring precipitation for 1991-2012 (Tables $5 \mathrm{~b}, \mathrm{~d}, \mathrm{e}$ ). These decreasing coastal precipitation trends for autumn, winter, and spring correspond with a decreasing trend in winter (September through May) glacier mass-balance at Mittivakkat Gletscher, illustrating a link between regional climate change and observations of glacier response. This corroborates Mernild et al. (2008b) who found a significant linear relationship (1995/96-2002/03) between uncorrected winter precipitation at Tasiilaq and Mittivakkat Gletscher winter balance ( $\mathrm{n}=8, r^{2}=0.68, p<0.01$ ), and a less strong (but still statistically significant) relationship $\left(\mathrm{n}=8, r^{2}=0.55, p<0.025\right)$ between mean summer temperature at Tasiilaq and Mittivakkat Gletscher summer balance (1995/96-2002/03).

\subsection{Highest 24-hour precipitation and number of precipitation days}

The annual coastal precipitation sum is shown in Figure 7 together with the highest 24-hour precipitation (a proxy of precipitation intensity) and the annual number of days with precipitation. A high annual precipitation sum corresponds to a high number of precipitation days, and vice versa, as shown using linear regression $\left(r^{2}\right.$ $=0.59$ and $p<0.01$ ). For the coastal precipitation interval from 0 to $500 \mathrm{~mm}$ w.e. $\mathrm{yr}^{-1}$ the range in the annual number of days with precipitation varies between $c .50$ to 175 days (having a mean and standard deviation of $96 \pm 32$ days). In comparison, above 
1,000 $\mathrm{mm}$ w.e. $\mathrm{yr}^{-1}$ the range is between $c$. 100 to 200 days ( $153 \pm 23$ days). The difference in mean and standard deviations between the two intervals indicates that for high annual precipitations $\left(>1,000 \mathrm{~mm}\right.$ w.e. $\left.\mathrm{yr}^{-1}\right)$ the number of precipitation days was higher but the spread in the number of days was lower, and vice versa for the 0 to $500 \mathrm{~mm}$ w.e. $\mathrm{yr}^{-1}$ interval. Regarding a potential link between the annual precipitation sum and the highest 24-hour precipitation, a significant $(p<0.01)$ correlation of 0.54 was found, indicating that years of high annual precipitation tend to have the highest 24-hour precipitation (Figure 7).

\section{Conclusions and perspective}

In Greenland there is significant variability in precipitation conditions and trends among coastal meteorological stations and ice cores through time since 1890. Precipitation on both annual and seasonal time-scales decreased with increasing latitude and increasing distance from the coast and inland towards the ice-sheet margin, likely explained by the distance from the oceanic moisture source and the orographic effect of near-coastal mountains.

Our EOF analysis provides two insights. First, there is an overall spatiotemporal cycle of precipitation captured in the EOF1 mode that is linked to the NAO and AMO and with an approximately six years lag time response to the GBI. All but three records of precipitation are linked to this pattern. Second, there is a clear potentially important separation of coastal and ice-core series that is strongly linked to the NAO, indicating a NAO-driven oscillation between inland and coastal precipitation patterns. We note, however, that while the patterns are clear in the spatial segregation and correlation with NAO, the second EOF2 mode actually captures only a small potentially non-significant amount of variation. This might change with a more spatially resolved set of data.

A distinct increase in coastal precipitation occurred around 1960, and coastal precipitation was almost in anti-phase with the (running mean) variability in the AMO-index (1925-1995) and the ice-core estimated GrIS precipitation time-series. This indicates that major changes in the mean annual precipitation pattern of around $500 \mathrm{~mm}$ w.e. $\mathrm{yr}^{-1}$ can occur within a 5-10 years timeframe. It is important to highlight and understand such rapid changes in the Greenland precipitation patterns to improve the reliability of future climate projections, since such rapid precipitation changes 
during climate warming may influence coastal glacier mass balance and water budgets, including freshwater runoff from Greenland to the adjacent ocean.

\section{Acknowledgement}

The ice core data were developed with support from NSF and NASA, including NSF grants 0909541, 1023672, and 1204176 which funded the collection and analyses of a number of recent ice cores records. We gratefully acknowledge assistance from logistics and drilling personnel in the field as well as students and staff in the Reno laboratory, Nevada. Special thanks are given to the Danish Meteorological Institute for providing observed meteorological station data. A.P.B. was funded by CONICYT, Chile (Grant Reference: MEC80120004). The authors have no conflict of interest. 


\section{References}

Allerup P, Madsen H, Vejen F. 1998. Estimating true precipitation in arctic areas. Proceedings of the Nordic Hydrological Conference. Helsinki: Nordic Hydrological Programme Report, 44, 1-9.

Allerup P, Madsen H, Vejen F. 2000. Correction of precipitation based on off-site weather information. Atmosphere Research, 53, 231-250.

Bales RC, Guo Q, Shen D, McConnell JR, Du G, Burkhart JF, Spikes VB, Hanna E, Cappelen J. 2009. Annual accumulation for Greenland updated using ice core data developed during 2000-2006 and analysis of daily coastal meteorological data. $J$. Geophys. Res., 114, D06116, doi:10.1029/2008JD011208.

Box JE, Cappelen J, Chen C, Decker D, Fettweis X, Mote T, Tedesco M, van de Wal RSW, Wahr J. 2012. Greenland Ice Sheet [in Arctic Report Card 2012], http://www.arctic.noaa.gov/reportcard, 146-158.

Box JE, Bromwich DH, Veenhuis BA, Bai L-S, Stroeve JC, Rogers JC, Steffen K, Haran T, Wang S-H. 2006. Greenland ice sheet surface mass balance variability (1988-2004) from calibrated Polar MM5 output. Journal of Climate, 19, 2783-2800.

Cappelen J. (ed). 2013a. Greenland - DMI Historical Climate Data Collection 18732012 - with Danish Abstracts. DMI Technical report 13-04, Copenhagen, pp. 74, www.dmi.dk/dmi/tr13-04.

Cappelen J. (ed). 2013b. Weather and climate data from Greenland 1958-2012 Observation data with description. DMI Technical report 13-11, Copenhagen, pp. 23, www.dmi.dk/dmi/tr13-11.

Chylek P, Dubey MK, Lesins G. 2006. Greenland warming of 1920-1930 and 19952005. Geophysical Research Letters, 33, L11707, doi:10.1029/2006GL026510. 
Chylek P, Folland C, Lesins G, Dubey M. 2010. Twentieth century bipolar seesaw of the Arctic and Antarctic surface air temperature. Geophysical Research Letters, 37, L08703, doi:10.1029/2010GL042793.

Chylek P, Folland C, Lesins G, Wang M, Dubey M. 2009. Arctic air temperature change amplification and the Atlantic Multidecadal Oscillation. Geophysical Research Letters, 36, L14801, doi:10.1029/2009GL038777.

Ettema J, van den Broeke MR, van Meijgaard E, van den Berg WJ, Bamber JL, Box JE, Bales RC. 2009. Higher surface mass balance of the Greenland ice sheet revealed by high-resolution climate modeling. Geophysical Research Letters, 36, L12501, doi:10.1029/2009GL038110.

Fang Z-F. 2004. Statistical relationship between the northern hemisphere sea ice and atmospheric circulation during wintertime. In Zhu, X. (Ed.) Observation, Theory and Modeling of Atmospheric Variability. World Scientific Series on Meteorology of East Asia. World Scientific Publishing Company, pp. 131-141.

Fettweis X, Hanna E, Gallee H, Huybrechts P, Erpicum M. 2008. Estimation of the Greenland ice sheet surface mass balance during 20th and 21st centuries. Cryosphere, 2, 117-129.

Folland CK, Palmer T, Parker DE. 1986. Sahel rainfall and worldwide sea temperatures. Nature, 320, 602-607.

Goodison BE, Sevruk B, Klemm S. 1989. WMO solid precipitation measurement intercomparison: objectives, methodology, analysis. IAHS publication, 179, 57-64.

Hanna E, Huybrechts P, Janssens I, Cappelen J, Steffen K, Stephens A. 2005. Runoff and mass balance of the Greenland ice sheet: 1958-2003. J. Geophys. Res., 110, D13108, doi:10.1029/2004JD005641. 
Hanna E, McConnell J, Das S, Cappelen J, Stephens A. 2006. Observed and modelled Greenland Ice Sheet snow accumulation, 1958-2003, and links with regional climate forcing. Journal of Climate, 19(3), 344-358, doi:10.1175/JCLI3615.1

Hanna E, Huybrechte P, Steffen K, Cappelen J, Huff R, Shuman C, Irvine-Fynn T, Wise S, Griffiths M. 2008. Increased runoff from melt from the Greenland ice sheet: A response to global warming. Journal of Climate, 21, 331-341.

Hanna E, Cappelen J, Fettweis X, Huybrechts P, Luckman A, Ribergaard MH. 2009. Hydrologic response of the Greenland Ice Sheet: the role of oceanographic forcing. Hydrological Processes (Special Issue: Hydrologic Effects of a Shrinking Cryosphere), 23(1), 7-30, doi:10.1002/hyp.7090.

Hanna E, Huybrechts P, Cappelen J, Steffen K, Bales RC, Burgess EW, McConnell JR, Steffensen JP, van den Broeke M, Wake L, Bigg GR, Griffiths M, Savas D. 2011. Greenland Ice Sheet surface mass balance 1870 to 2010 based on Twentieth Century Reanalysis, and links with global climate forcing. Journal of Geophysical Research Atmospheres, 116, D24121, doi:10.1029/2011JD016387

Hanna E, Mernild SH, Cappelen J, Steffen K. 2012. Recent warming in Greenland in a long-term instrumental (1881-2012) climatic context. Part 1: Evaluation of surface air temperature records. Environmental Research Letters, 7, 045404, doi:10.1088/1748-9326/7/4/045404.

Hanna E, Cappelen J, Fettweis X, Mernild SH, Mote T, Steffen K, Wood L. 2013a. Atmospheric and oceanic climatic forcing of the exceptional Greenland Ice Sheet surface melt in summer 2012. Int. J. Climatol., doi:10.1002/joc.3743.

Hanna E, Navarro FJ, Pattyn F, Domingues C, Fettweis X, Ivins E, Nicholls RJ, Ritz C, Smith B, Tulaczyk S, Whitehouse P, Zwally J. 2013b. Ice-sheet mass balance and climate change. Nature, 498, 51-59, doi: 10.1038/nature12238.

Hanna E, Jones JM, Cappelen J, Mernild SH, Wood L, Steffen K, Huybrechts P. 2013c. The influence of North Atlantic atmospheric and oceanic forcing effects on 
1900-2010 Greenland summer climate and ice melt/runoff. Int. J. Climatol., 33, 862880, doi: $10.1002 /$ joc. 3475 .

Hurrell JW, van Loon H. 1997. Decadal variations in climate associated with the North Atlantic Oscillation, Climate Change, 36, 301-326.

IPCC 2013. Summary for Policymakers. [online: http://www.climatechange2013.org/ images/uploads/WGIAR5-SPM_Approved27Sep2013.pdf].

Kaplan A, Cane MA, Kushnir Y, Clement AC. 1998. Analyses of global sea surface temperatures 1856-1991. J. Geophys. Res., 103, 18575-18589.

Kerr RA. 2000. A North Atlantic climate pacemaker for the centuries. Science, 288, 1984-1985.

Knudsen MF, Seidenkrantz M-S, Jacobsen BH, Kuijpers A. 2011. Tracking the Atlantic multidecadal oscillation through the last 8,000 years. Nature Communications, 2, 178.

Knudsen NT, Hasholt B. 2008. Mass balance observations at Mittivakkat Glacier, Ammassalik Island, Southeast Greenland 1995-2006. Geografisk Tidsskrift-Danish Journal of Geography, 108(1), 111-120.

Liston GE, Mernild SH. 2012. Greenland freshwater runoff. Part I: A runoff routing model for glaciated and non-glaciated landscapes (HydroFlow). Journal of Climate, 25(17), 5997-6014.

McConnell JR, Edwards R, Kok GL, Flanner MG, Zender CS, Saltzman ES, Banta JS, Pasteris DR, Carter MM, Kahl JDW. 2007. 20 th century industrial black carbon emissions altered Arctic climate forcing. Science, 317, 1381-1384, doi:10.1126/science.1144856. 
McConnell JR, Lamorey GW, Lambert SW, Taylor KC. 2002. Continuous ice-core chemical analyses using inductively coupled plasma mass spectrometry. Environmental Science \& Technology, 36(1), 7-11.

McConnell JR, Mosley-Thompson E, Bromwich DH, Bales RC, Kyne J. 2000. Interannual variations of snow accumulation on the Greenland Ice Sheet (1985-1996): New observations versus model predictions. Journal of Geophysical Research, 105, 4039-4046.

McGrath D, Colgan W, Bayou N, Muto A, Steffen K. 2013. Recent warming at Summit, Greenland: Global context and implications. Geophysical Research Letters, 40, doi:10.1002/grl.50456.

Marzeion B, Jarosch AH, Hofer M. 2012. Past and future sea-level change from the surface mass balance of glaciers. The Cryosphere, 6, 1295-1322. doi 10.5194/tc-61295-2012.

Mernild SH, Hanna E, Yde JC, Cappelen J, Malmros JK 2013c. Coastal Greenland air temperature extremes and trends 1890-2010: Annual and monthly analysis. International Journal of Climatology, doi: 10.1002/joc.3777.

Mernild SH, Kane DL, Hansen BU, Jakobsen BH, Hasholt B, Knudsen NT. 2008b. Climate, glacier mass balance, and runoff (1993-2005) for the Mittivakkat Glacier catchment, Ammassalik Island, SE Greenland, and in a long term perspective (18981993), Hydrol. Res., 39(4), 239-256.

Mernild SH, Knudsen NT, Lipscomb WH, Yde JC, Malmros JK, Jakobsen BH, Hasholt B. 2011a. Increasing mass loss from Greenland's Mittivakkat Gletscher. The Cryosphere, 5, 341-348, doi:10.5194/tc-5-341-2011.

Mernild SH, Knudsen NT, Hoffman MJ, Yde JC, Lipscomb WL, Hanna E, Malmros JK, Fausto RS. 2013b. Volume and Velocity chanages at Mittivakkat Gletscher, Southeast Greenland, 1994-2012. Journal of Glaciology, 59(216), 660-670, doi:10.3189/2013JoG13J017. 
Mernild SH, Liston GE. 2012. Greenland freshwater runoff. Part II: Distribution and trends, 1960-2010. Journal of Climate, 25(17), 6015-6035.

Mernild SH, Liston GE, Hiemstra CA, Christensen JH. 2010a. Greenland Ice Sheet surface mass-balance modeling in a 131-year perspective 1950-2080. Journal of Hydrometeorology, 11(1), 3-25.

Mernild SH, Liston GE, Hiemstra CA, Christensen JH, Stendel M, Hasholt B. 2011c. Surface mass-balance and runoff modeling using HIRHAM4 RCM at Kangerlussuaq (Søndre Strømfjord), West Greenland, 1950-2080. Journal of Climate, 24(3), 609623, doi: 10.1175/2010 JCLI3560.1.

Mernild SH, Liston GE, Hiemstra CA, Steffen K, 2008a. Surface Melt Area and Water Balance Modeling on the Greenland Ice Sheet 1995-2005. Journal of Hydrometeorology, 9(6): 1191-1211.

Mernild SH, Liston GE, Steffen K, Chylek P. 2010b. Meltwater flux and runoff modeling in the ablation area of the Jakobshavn Isbræ, West Greenland. Journal of Glaciology, 56(195), 20-32.

Mernild SH, Lipscomb WH, Bahr DB, Radić V, Zemp M. 2013a. Global glacier retreat: A revised assessment of committed mass losses and sampling uncertainties. The Cryosphere, 7, 1565-1577, doi:10.5194/tc-7-1565-2013.

Mernild SH, Mote T, Liston GE. 2011b. Greenland Ice Sheet surface melt extent and trends, 1960-2010. Journal of Glaciology, 57(204), 621-628.

Mernild SH, Pelto M, Malmros JK, Yde JC, Knudsen NT, Hanna E. 2013c. Identification of ablation rate, ELA, AAR, and net mass balance using transient snowline variations on two Arctic glaciers. Journal of Glaciology, 59(216), 649-659, doi:10.3189/2013JoG12J221. 
Mernild SH, Seidenkrantz M-S, Chylek P, Liston GE, Hasholt B. 2012. Climatedriven fluctuations in freshwater to Sermilik Fjord, East Greenland, during the last 4000 years. The Holocene, 22(2), 155-164. doi:10.1177/0959683611431215.

Metcalfe JR, Ishida S, Goodison BE. 1994. A corrected precipitation archive for the Northwest Territories of Canada, http://www.usask.ca/geography/MAGS/Data/Public_Data/precip_corr/pcpncor_e.htm

Mikkelsen AB, Hasholt B, Knudsen NT, Nielsen MN. 2013. Jokulhlaups and sediment transport in Watson River, Kangerlussuaq, West Greenland. Hydrology Research, 41(1), 58-67.

Radić V, Hock R. 2011. Regionally differentiated contribution of mountain glaciers and ice caps to future sea-level rise, Nat. Geosci., 4, 91-94.

Rennermalm AK, Smith LC, Chu VW, Forster RR, Box JE, Hagedorn B. 2012. Proglacial River Dataset from the Akuliarusiarsuup Kuua River Northern Tributary, Southwest Greenland, 2008-2010. Earth System Science Data, 4, 1-12, doi:10.5194/essd-4-1-2012.

Schlesinger ME, Ramankutty N. 1994. An oscillation in the global climate system of period 65-70 years. Nature, $\mathbf{3 6 7}, 723$.

Sigl M, McConnell JR, Layman L, Maselli O, McGwire K, Pasteris D, Dahl-Jensen D, Steffensen JP, Edwards R, Mulvaney R. 2013. A new bipolar ice core record of volcanism from WAIS Divide and NEEM and implications for climate forcing of the last 2000 years, J. Geophys. Res., 118, 1151-1169, doi:10.1029/2012JD018603.

Steffen K, Box JE. 2001. Surface climatology of the Greenland Ice Sheet: Greenland climate network 1995-1999. Journal of Geophysical Research, 16(D24), 3395133964.

Steffensen P, 1996. Standard Normal Homogeneity Test for Windows. DMI Technical Report 96-13, Copenhagen, pp. 35. 
Steffensen P, Larsen FL, Cappelen J. 1993. Homogeneity test of climatological data. DMI Technical Report 93-12, Copenhagen, pp. 22.

Straneo F, Hamilton GS, Sutherland DA, Stearns LA, Davidson F, Hammillet MO, Stenson GB, Rosing-Asvid A. 2010. Rapid circulation of warm subtropical waters in a major glacial fjord in East Greenland, Nature Geoscience, 3, 182-186.

Straneo F, Heimbach P, Sergienko O, Hamilton G, Catania G, Griffies S, Hallberg R, Jenkins A, Joughin I, Motyka R, Pfeffer WT, Price SF, Rignot E, Scambos T, Truffer M, Vieli A. 2013. Challenges to understanding the dynamic response of Greenland's marine terminating glaciers to oceanic and atmospheric forcing. Bull. Amer. Meteor. Soc., 8, 1131-1144, doi:10.1175/BAMS-D-12-00100.

van den Broeke MR, Bamber J, Ettema J, Rignot E, Schrama E, vab de Berg WJ, van Meijgaard E, Velicogna I, Wouters B. 2009. Partitioning recent Greenland mass loss. Science, 326, 984-986.

Yang D, Ishida S, Goodison BE, Gunter T. 1999. Bias correction of daily precipitation measurements for Greenland. Journal of Geophysical Research, 104(D6), 6171-6181, doi: 10.1029/1998JD200110. 
Figure 1: Location map of Greenland Danish Meteorological Institute coastal climate stations and ice core locations used in this study.

Figure 2: Time-series of Greenland precipitation anomaly sum from coastal stations and from GrIS ice cores, where dots represent the annual precipitation, including 10year running means and trend lines: (a) coastal composite mean annual precipitation (CGP1) (Aassiaat, Nuuk, Narsarsuaq, Qaqortoq, Danmarkshavn, Ittoqqortoomiit, and Tasiilaq; 1961-2012) and CGP2 (Nuuk and Tasiilaq; 1900-2012), composite GrIS ice core mean annual precipitation (CGIC), and AMO; (b) composite mean seasonal CGP1; and (c) composite mean seasonal CGP2. Note the different scales on the ordinate.

Figure 3: Time-series of GrIS ice core estimated annual precipitation, including 10year running mean, trend lines, and AMO: (a) three examples of ice core estimated precipitation sum covering the period 1890 through 2009/2010; and (b) composite mean annual ice-core estimated precipitation anomaly time series for the GrIS and the three sectors: north, center, and south (1890-2000) (for location of the sectors, see Figure 1).

Figure 4: Greenland precipitation time series (1890-2012) based on the Empirical Orthogonal Functions: (a) EOF1; and (b) EOF2. SC equals the square covariance, and maps of the interpolated eigenvectors for (c) EOF1 and (d) EOF2 show the spatiotemporal signature of Greenland precipitation.

Figure 5: Eigenvector correlation values for each site for both: (a) EOF1; and (b) EOF2.

Figure 6: (a) EOF1; and (b) EOF2 cross correlation relationships between the NAO Index, AMO Index, and GBI. The horizontal dashed line indicates the line of significance.

Figure 7: Linear correlations between annual precipitation sum and the highest 24hour precipitation on annual scale and the annual number of days with precipitation, only for the coastal stations marked with red in Figure 1. 
Table 1: Details of the coastal Greenland meteorological stations used in this study.

Table 2: Details of the Greenland Ice Sheet ice cores used in this study.

Table 3: (a) Annual; (b) spring (MAM); (c) summer (JJA); (d) autumn (SON); and (e) winter (DJF) precipitation sum and standard deviations ( $\left.\mathrm{mm} \mathrm{w.e.} \mathrm{yr}^{-1}\right)$ at coastal DMI Greenland climate stations for climatological normal and shorter recent periods. The ' $x$ ' indicates "no value".

Table 4: Annual ice core estimated precipitation sum and standard deviations ( $\mathrm{mm}$ w.e. $\mathrm{yr}^{-1}$ ) for climatological normal and shorter recent periods.

Table 5: (a) Greenland coastal annual precipitation; (b) spring (MAM); (c) summer (JJA); (d) autumn (SON); and (e) winter trends (DJF) (mm w.e. $\mathrm{yr}^{-2}$ ) for climatological normal and shorter recent periods. Significant trends $(p<0.05)$ are highlighted in bold type.

Table 6: Greenland Ice Sheet ice core estimated annual precipitation ( $\mathrm{mm}$ w.e. $\left.\mathrm{yr}^{-2}\right)$ for climatological normal and shorter recent periods. Significant trends $(p<0.05)$ are highlighted in bold type.

Table 7: Monthly, seasonal, and yearly driest and wettest precipitation sums at coastal DMI Greenland climate stations ( $\mathrm{mm}$ w.e. $\mathrm{yr}^{-1}$ ). Driest and wettest records since 2000 are highlighted in bold. In case the monthly precipitation is zero for two or more months, the latest year of occurrence is mentioned in brackets.

Table 8: Yearly driest and wettest ice core estimated precipitation sums ( $\mathrm{mm}$ w.e. $\mathrm{yr}^{-}$ 1). The year of occurrence is shown in brackets. 


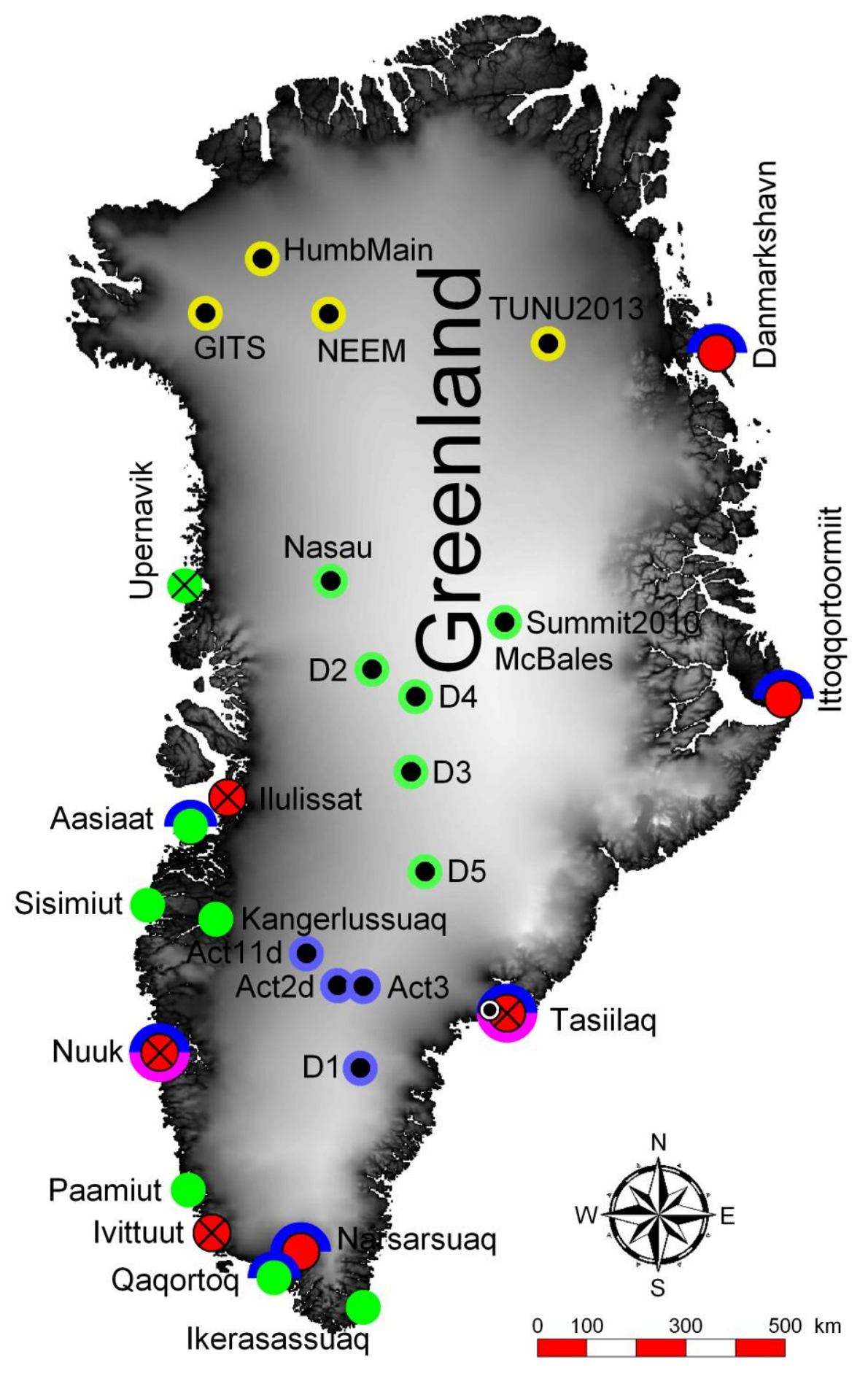

Station with precipitation sum (DMI)

- Ice core locations (north)

Station with precipitation sum and highest 24-hour precipitation (DMI)

- Ice core locations (center)

X Data extending back before 1900

- Ice core locations (south)

Composite Greenland Precipitation 1 (CGP1)

() Mittivakkat Gletscher

Composite Greenland Precipitation 2 (CGP2)

Figure 1: Location map of Greenland Danish Meteorological Institute coastal climate stations and ice core locations used in this study. 

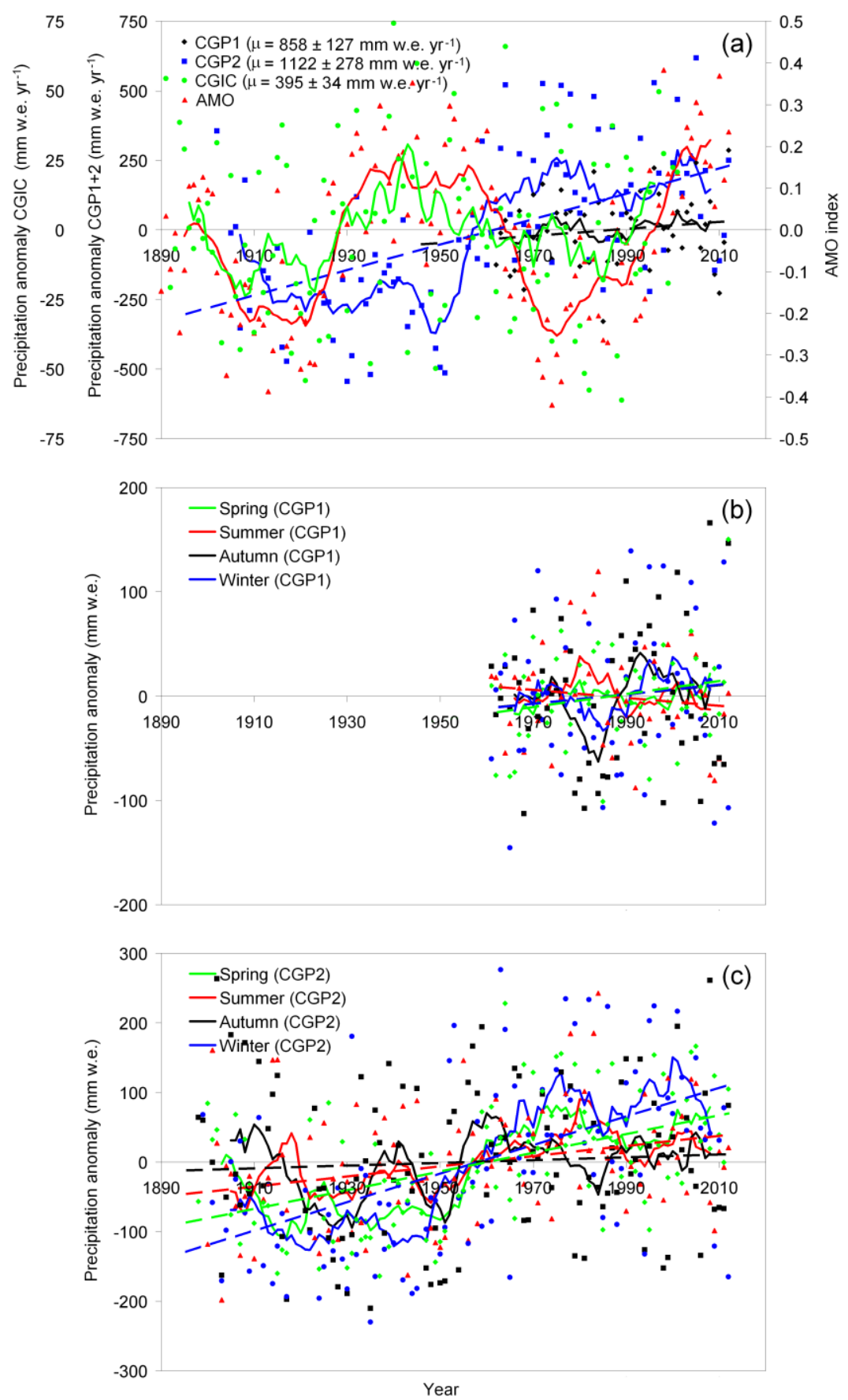

Figure 2: Time-series of Greenland precipitation anomaly sum from coastal stations and from GrIS ice cores, where dots represent the annual precipitation, including 10year running means and trend lines: (a) coastal composite mean annual precipitation (CGP1) (Aassiaat, Nuuk, Narsarsuaq, Qaqortoq, Danmarkshavn, Ittoqqortoomiit, and Tasiilaq; 1961-2012) and CGP2 (Nuuk and Tasiilaq; 1900-2012), composite GrIS ice core mean annual precipitation (CGIC), and AMO; (b) composite mean seasonal CGP1; and (c) composite mean seasonal CGP2. Note the different scales on the ordinate. 

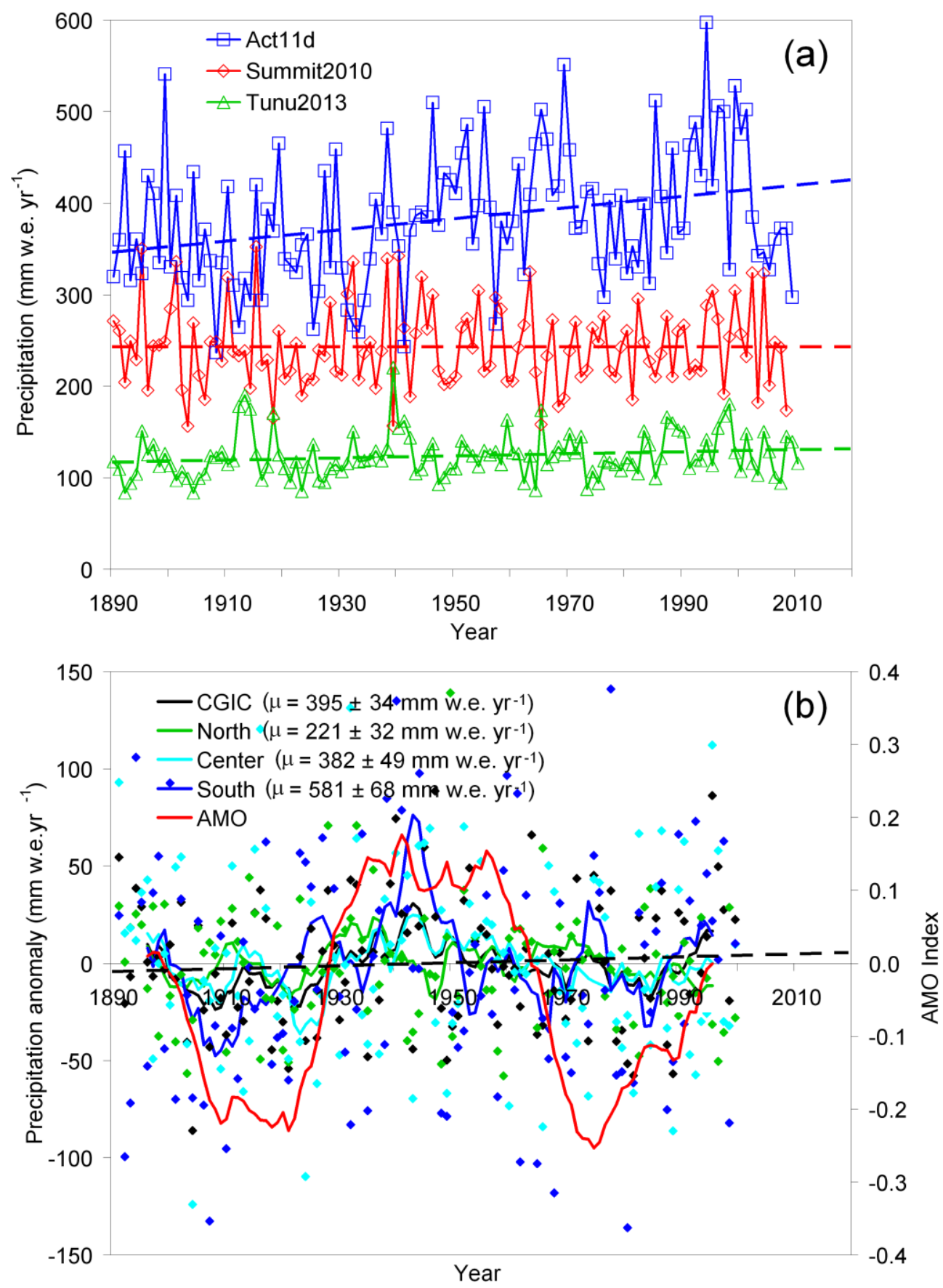

Figure 3: Time-series of GrIS ice core estimated annual precipitation, including 10year running mean, trend lines, and AMO: (a) three examples of ice core estimated precipitation sum covering the period 1890 through 2009/2010; and (b) composite mean annual ice-core estimated precipitation anomaly time series for the GrIS and the three sectors: north, center, and south (1890-2000) (for location of the sectors, see Figure 1). 

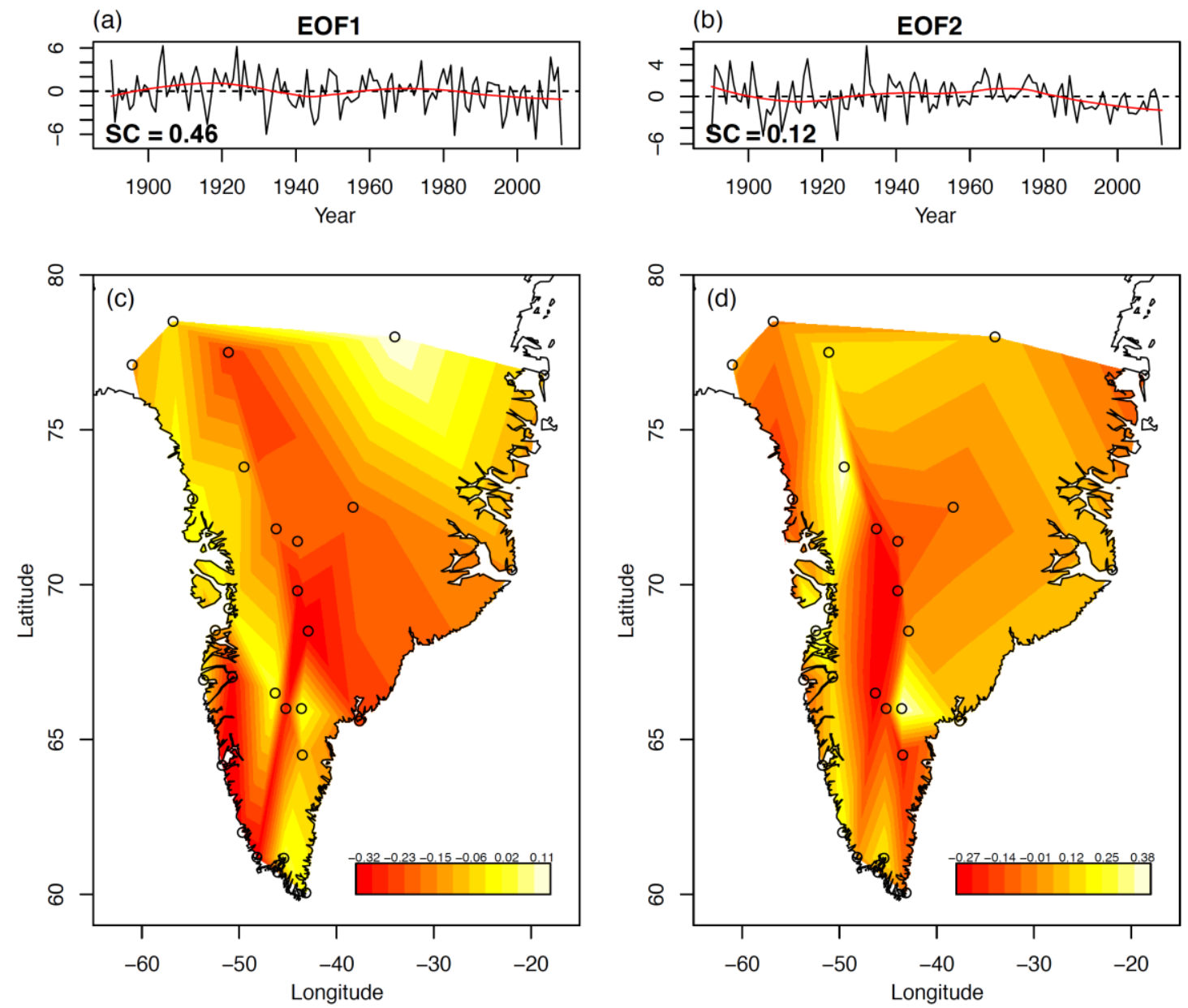

Figure 4: Greenland precipitation time series (1890-2012) based on the Empirical Orthogonal Functions: (a) EOF1; and (b) EOF2. SC equals the square covariance, and maps of the interpolated eigenvectors for (c) EOF1 and (d) EOF2 show the spatiotemporal signature of Greenland precipitation. 


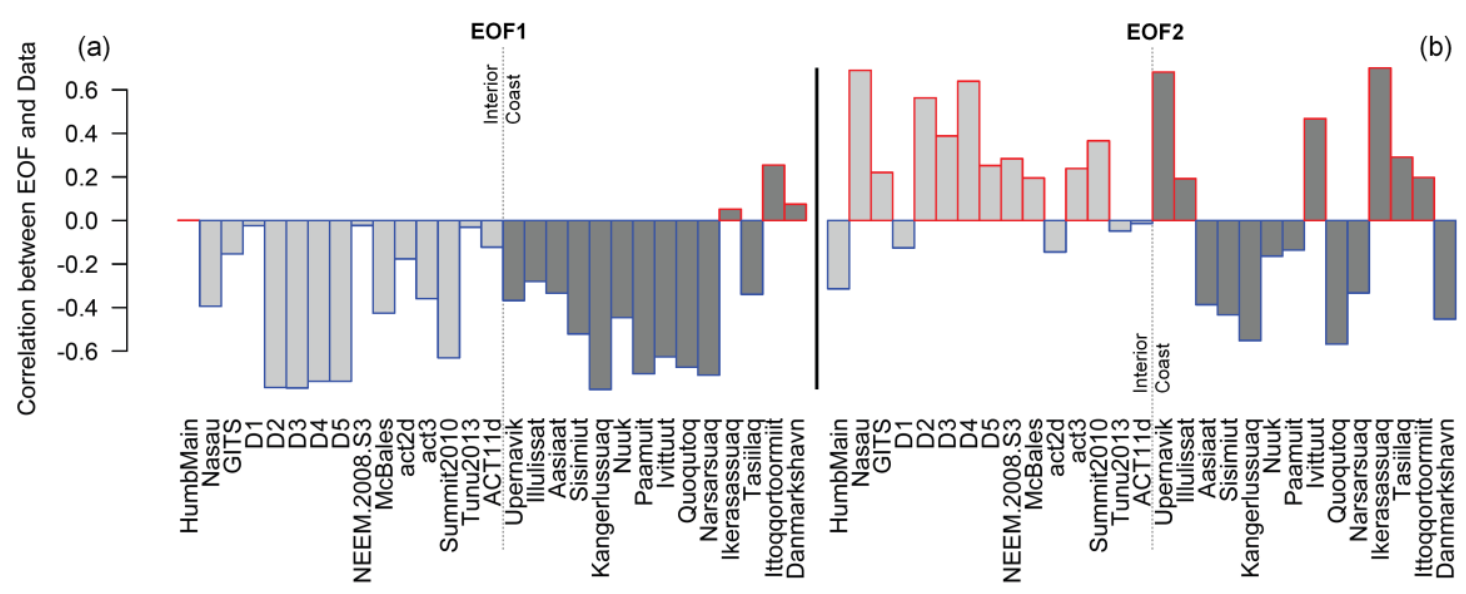

Figure 5: Eigenvector correlation values for each site for both: (a) EOF1; and (b) EOF2. 
(a) EOF1
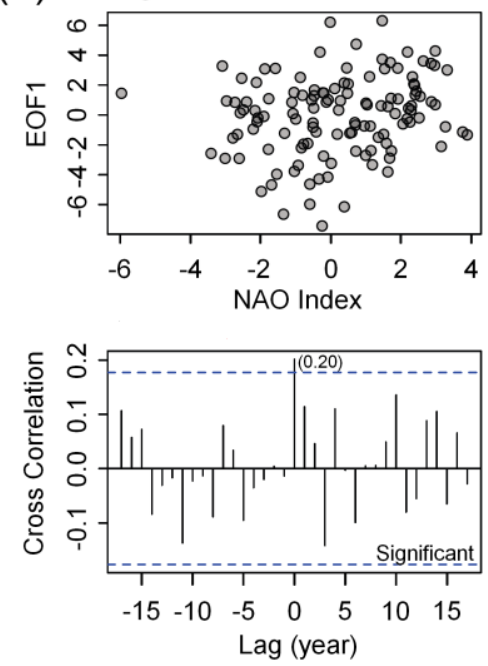

\section{(b) EOF2}
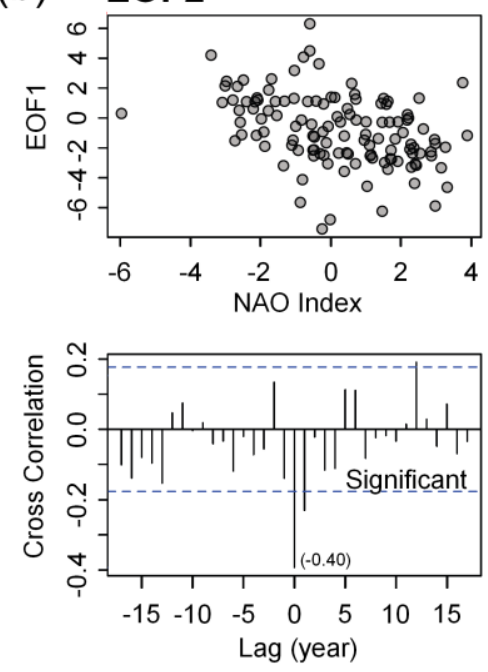
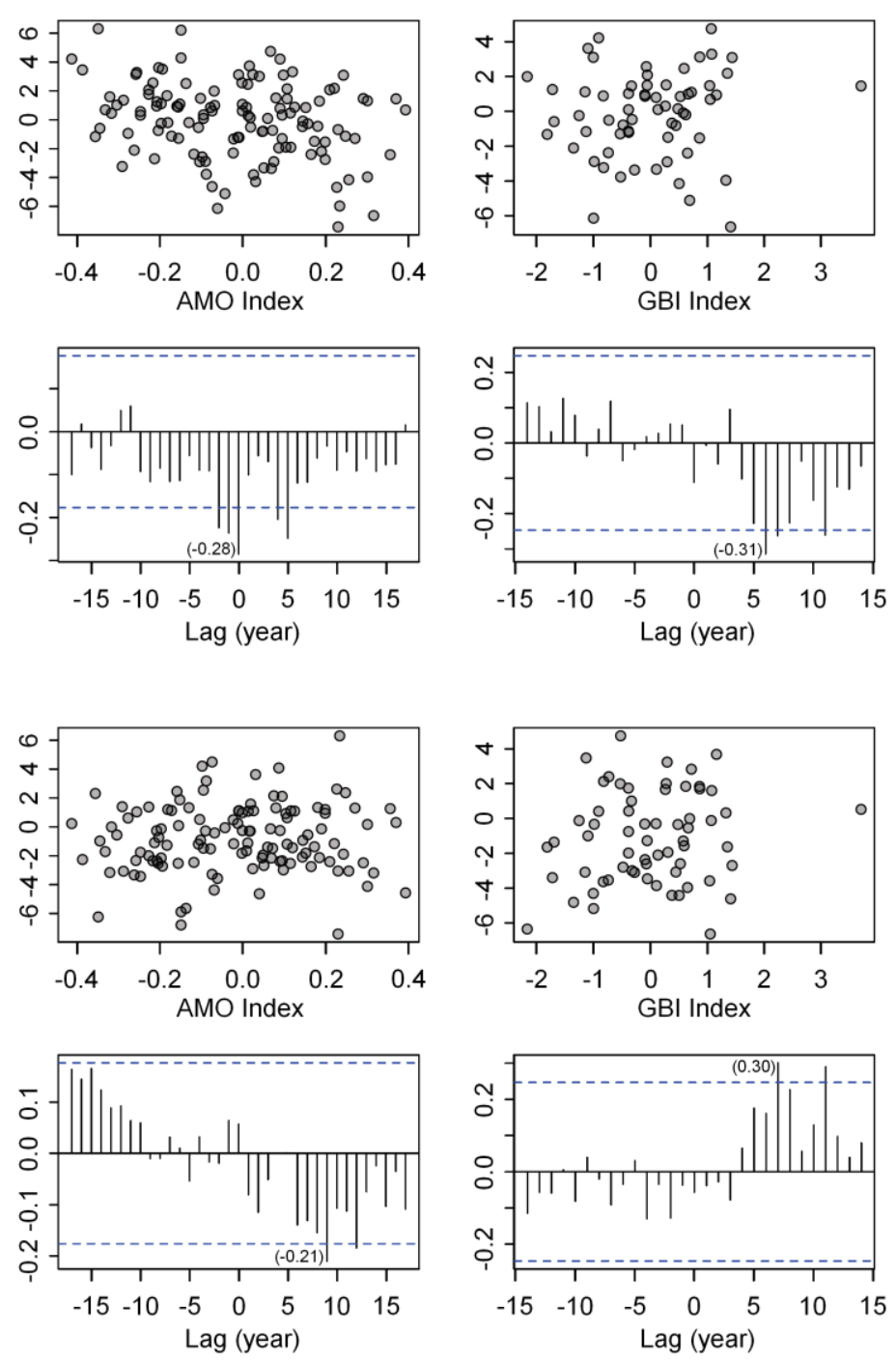

Figure 6: (a) EOF1; and (b) EOF2 cross correlation relationships between the NAO Index, AMO Index, and GBI. The horizontal dashed line indicates the line of significance. 


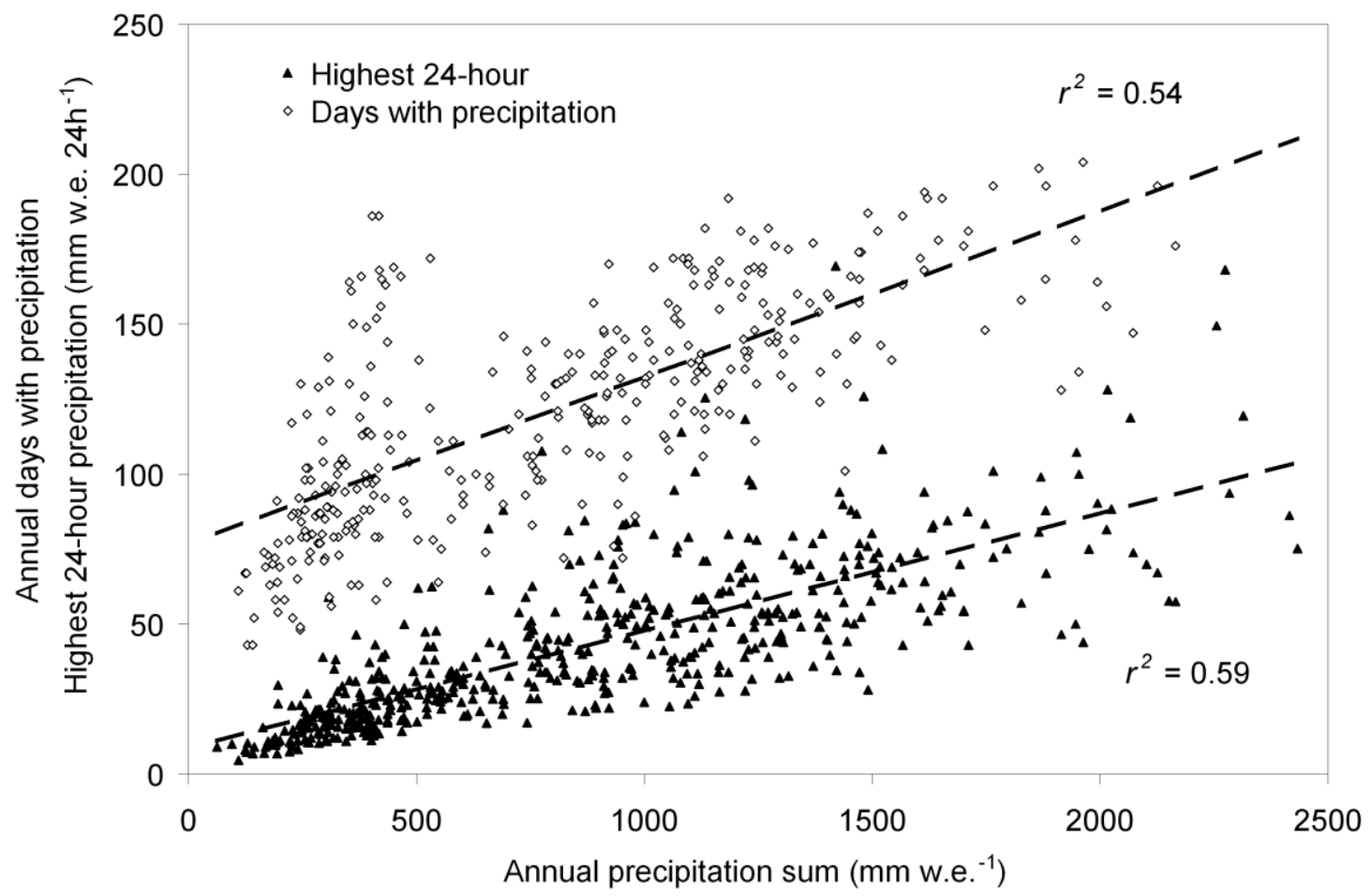

Figure 7: Linear correlations between annual precipitation sum and the highest 24hour precipitation on annual scale and the annual number of days with precipitation, only for the coastal stations marked with red in Figure 1. 
Table 1: Details of the coastal Greenland meteorological stations used in this study.

\begin{tabular}{|c|c|c|c|c|c|c|}
\hline Station & $\begin{array}{c}\text { DMI operated } \\
\text { meteorological stations } \\
\text { with the World } \\
\text { Meteorological } \\
\text { Organization (WMO) } \\
\text { code }\end{array}$ & $\begin{array}{l}\text { Latitude } \\
\left({ }^{\circ} \mathrm{N}\right)\end{array}$ & $\begin{array}{l}\text { Longitude } \\
\left({ }^{\circ} \mathrm{W}\right)\end{array}$ & Available data period & $\begin{array}{l}\text { Precipitation } \\
\text { parameters }\end{array}$ & $\begin{array}{l}\text { Mean } \\
\text { precipitation } \\
\text { bias } \\
\text { correction } \\
\text { factor }\end{array}$ \\
\hline Upernavik & $34210 / 04210 / 04211$ & 72.78 & 56.13 & Jan 1890-Dec 1980 & Sum & 1.55 \\
\hline Aasiaat ${ }^{*}$ & 04220 & 68.70 & 52.75 & Jan 1958-present & Sum & 1.56 \\
\hline Ilulissat & $34216 / 04216 / 04221$ & 69.23 & 51.07 & Jan 1890-Dec 1984 & $\begin{array}{c}\text { Sum } \\
\text { Highest 24-hour }\end{array}$ & 1.43 \\
\hline Sisimiut & $4230 / 4234$ & 66.92 & 53.67 & $\begin{array}{c}\text { Jan 1961-present } \\
\text { (excl. 1993-2001 } \\
\text { and 2004-2008) }\end{array}$ & Sum & 1.54 \\
\hline Kangerlussuaq $^{*}$ & 04231 & 67.02 & 50.70 & Jan 1976-present & Sum & 1.46 \\
\hline Nuuk $^{* * * *}$ & $34250 / 04250$ & 64.17 & 51.75 & Jan 1890-present & $\begin{array}{c}\text { Sum } \\
{\text { Highest } 24-\text { hour }^{\dagger}}^{-}\end{array}$ & 1.54 \\
\hline Paamiut & 04260 & 62.00 & 49.67 & Jan 1958-Aug 1992 & Sum & 1.37 \\
\hline Ivittuut & 34262 & 61.20 & 48.18 & Jan 1890-Dec 1960 & $\begin{array}{c}\text { Sum } \\
\text { Highest 24-hour }\end{array}$ & 1.36 \\
\hline Narsarsuaq* & 04270 & 61.17 & 45.42 & Jan 1961-present & $\begin{array}{c}\text { Sum } \\
\text { Highest } 24 \text {-hour }\end{array}$ & 1.27 \\
\hline Qaqortoq $^{*}$ & 04272 & 60.72 & 46.05 & Jan 1961-present & Sum & 1.33 \\
\hline Danmarkshavn* & 04320 & 76.76 & 18.67 & Jan 1949-present & $\begin{array}{c}\text { Sum } \\
\text { Highest 24-hour }\end{array}$ & 1.74 \\
\hline Ittoqqortoormiit* & $34339 / 04339$ & 70.48 & 21.95 & Jan 1950-present & $\begin{array}{c}\text { Sum } \\
\text { Highest 24-hour }\end{array}$ & 1.48 \\
\hline Tasiilaq,*** & $34360 / 04360$ & 65.60 & 37.63 & Jan 1898-present & $\begin{array}{c}\text { Sum } \\
\text { Highest 24-hour }\end{array}$ & 1.46 \\
\hline Ikerasassuaq & 04390 & 60.05 & 43.15 & $\begin{array}{l}\text { Jan 1958-present } \\
\text { (excl. 1981-1992) }\end{array}$ & Sum & 1.47 \\
\hline $\begin{array}{l}\text { Mean and } \\
\text { standard } \\
\text { deviation }\end{array}$ & ------- & -------- & -------- & ------- & -------- & $1.47 \pm 0.12$ \\
\hline
\end{tabular}

$\dagger$ The highest 24-hour precipitation rate covers the period 1922 through 2012.

* CGP1 (1961-2012).

** CGP2 (1890-2012). 
Table 2: Details of the Greenland Ice Sheet ice cores used in this study.

\begin{tabular}{|c|c|c|c|}
\hline Ice core & Latitude $\left({ }^{\circ} \mathrm{N}\right)$ & Longitude $\left({ }^{\circ} \mathrm{W}\right)$ & Available data period \\
\hline HumbMain & 78.5 & 56.8 & $1890-1994$ \\
\hline Nasau & 73.8 & 49.5 & $1890-1994$ \\
\hline GITS & 77.1 & 61.0 & $1890-1995$ \\
\hline D1 & 64.5 & 43.5 & $1890-1998$ \\
\hline D2 & 71.8 & 46.2 & $1890-1998$ \\
\hline D3 & 69.8 & 44.0 & $1890-1998$ \\
\hline D4 & 71.4 & 44.0 & $1890-2002$ \\
\hline D5 & 68.5 & 42.9 & $1890-2002$ \\
\hline NEEM-2008-S3 & 77.5 & 51.1 & $1890-2001$ \\
\hline McBales & 72.5 & 38.3 & $1890-2002$ \\
\hline Act2d & 66.0 & 45.2 & $1890-2003$ \\
\hline Act3 & 66.0 & 43.6 & $1890-2003$ \\
\hline Summit2010 & 72.5 & 38.3 & $1890-2009$ \\
\hline TUNU2013 & 78.0 & 34.0 & $1890-2010$ \\
\hline Act11d & 66.5 & 46.3 & $1890-2010$ \\
\hline
\end{tabular}


Table 3: (a) Annual; (b) spring (MAM); (c) summer (JJA); (d) autumn (SON); and (e) winter (DJF) precipitation sum and standard deviations $\left(\mathrm{mm}\right.$ w.e. $\left.\mathrm{yr}^{-1}\right)$ at coastal DMI Greenland climate stations for climatological normal and shorter recent periods. The ' $\mathrm{x}$ ' indicates "no value".

\begin{tabular}{|c|c|c|c|c|c|c|c|c|c|c|c|c|c|c|}
\hline (a) Year & Upernavik & Aasiaat & Ilulissat & Sisimiut & Kangerlussuaq & Nuuk & Paamiut & Ivittuut & Narsarsuaq & Qaqortoq & Danmarkshavn & Ittoqqortoormiit & Tasiilaq & Ikerasassuaq \\
\hline $2001-12$ & $\mathrm{x}$ & $541 \pm 144$ & $\mathrm{x}$ & $631 \pm 250$ & $258 \pm 63$ & $1369 \pm 339$ & $\mathrm{x}$ & $\mathrm{x}$ & $791 \pm 229$ & $1217 \pm 432$ & $302 \pm 94$ & $635 \pm 133$ & $1257 \pm 232$ & $2283 \pm 576$ \\
\hline 1991-2012 & $\mathrm{x}$ & $497 \pm 128$ & $\mathrm{x}$ & $624 \pm 233$ & $256 \pm 60$ & $1297 \pm 312$ & $\mathrm{x}$ & $\mathrm{x}$ & $830 \pm 221$ & $1358 \pm 374$ & $321 \pm 90$ & $605 \pm 132$ & $1276 \pm 300$ & $2191 \pm 482$ \\
\hline 1981-2012 & $\mathrm{x}$ & $501 \pm 113$ & $\mathrm{x}$ & $650 \pm 197$ & $242 \pm 63$ & $1225 \pm 318$ & $\mathrm{x}$ & $\mathrm{x}$ & $828 \pm 233$ & $1301 \pm 380$ & $314 \pm 97$ & $574 \pm 170$ & $1316 \pm 308$ & $\mathrm{x}$ \\
\hline $1971-2000$ & $\mathrm{x}$ & $494 \pm 100$ & $\mathrm{x}$ & $616 \pm 144$ & $\mathrm{x}$ & $1130 \pm 235$ & $\mathrm{x}$ & $\mathrm{x}$ & $817 \pm 230$ & $1262 \pm 336$ & $301 \pm 103$ & $624 \pm 237$ & $1437 \pm 371$ & $\mathrm{x}$ \\
\hline 1961-90 & $\mathrm{x}$ & $474 \pm 112$ & $\mathrm{x}$ & $593 \pm 148$ & $\mathrm{x}$ & $1159 \pm 223$ & $1201 \pm 273$ & $\mathrm{x}$ & $783 \pm 219$ & $1138 \pm 290$ & $246 \pm 100$ & $660 \pm 245$ & $1425 \pm 364$ & $\mathrm{x}$ \\
\hline $1951-80$ & $373 \pm 87$ & $\mathrm{x}$ & $368 \pm 78$ & $\mathrm{x}$ & $\mathrm{x}$ & $1129 \pm 246$ & $\mathrm{x}$ & $\mathrm{x}$ & $\mathrm{x}$ & $\mathrm{x}$ & $242 \pm 103$ & $687 \pm 224$ & $1338 \pm 385$ & $\mathrm{x}$ \\
\hline 1941-70 & $358 \pm 86$ & $\mathrm{x}$ & $377 \pm 112$ & $\mathrm{x}$ & $\mathrm{x}$ & $993 \pm 329$ & $\mathrm{x}$ & $\mathrm{x}$ & $\mathrm{x}$ & $\mathrm{x}$ & $\mathrm{x}$ & $\mathrm{x}$ & $1148 \pm 310$ & $\mathrm{x}$ \\
\hline $1931-60$ & $293 \pm 74$ & $\mathrm{x}$ & $371 \pm 121$ & $\mathrm{x}$ & $\mathrm{x}$ & $800 \pm 246$ & $\mathrm{x}$ & $1721 \pm 390$ & $\mathrm{x}$ & $\mathrm{x}$ & $\mathrm{x}$ & $\mathrm{x}$ & $1081 \pm 269$ & $\mathrm{x}$ \\
\hline $1921-50$ & $374 \pm 92$ & $\mathrm{x}$ & $368 \pm 122$ & $\mathrm{x}$ & $\mathrm{x}$ & $753 \pm 190$ & $\mathrm{x}$ & $1702 \pm 425$ & $\mathrm{x}$ & $\mathrm{x}$ & $\mathrm{x}$ & $\mathrm{x}$ & $1011 \pm 242$ & $\mathrm{x}$ \\
\hline $1911-40$ & $376 \pm 107$ & $\mathrm{x}$ & $353 \pm 105$ & $\mathrm{x}$ & $\mathrm{x}$ & $750 \pm 188$ & $\mathrm{x}$ & $1619 \pm 435$ & $\mathrm{x}$ & $\mathrm{x}$ & $\mathrm{x}$ & $\mathrm{x}$ & $1051 \pm 277$ & $\mathrm{x}$ \\
\hline 1901-30 & $343 \pm 122$ & $\mathrm{x}$ & $362 \pm 85$ & $\mathrm{x}$ & $\mathrm{x}$ & $752 \pm 192$ & $\mathrm{x}$ & $1405 \pm 272$ & $\mathrm{x}$ & $\mathrm{x}$ & $\mathrm{x}$ & $\mathrm{x}$ & $1142 \pm 372$ & $\mathrm{x}$ \\
\hline $1891-1920$ & $376 \pm 158$ & $\mathrm{x}$ & $334 \pm 98$ & $\mathrm{x}$ & $\mathrm{x}$ & $813 \pm 242$ & $\mathrm{x}$ & $1473 \pm 277$ & $\mathrm{x}$ & $\mathrm{x}$ & $\mathrm{x}$ & $\mathrm{x}$ & $\mathrm{x}$ & $\mathrm{x}$ \\
\hline 1891-1910 & $375 \pm 178$ & $\mathrm{x}$ & $302 \pm 69$ & $\mathrm{x}$ & $\mathrm{x}$ & $892 \pm 236$ & $\mathrm{x}$ & $1507 \pm 296$ & $\mathrm{x}$ & $\mathrm{x}$ & $\mathrm{x}$ & $\mathrm{x}$ & $\mathrm{x}$ & $\mathrm{x}$ \\
\hline
\end{tabular}

\begin{tabular}{|c|c|c|c|c|c|c|c|c|c|c|c|c|c|c|}
\hline (b) Spring & Upernavik & Aasiaat & Ilulissat & Sisimiut & Kangerlussuaq & Nuuk & Paamiut & Ivittuut & Narsarsuaq & Qaqortoq & Danmarkshavn & Ittoqqortoormiit & Tasiilaq & Ikerasassuaq \\
\hline $2001-12$ & $\mathrm{x}$ & $104 \pm 36$ & $\mathrm{x}$ & $99 \pm 47$ & $44 \pm 30$ & $277 \pm 125$ & $\mathrm{x}$ & $\mathrm{x}$ & $134 \pm 70$ & $218 \pm 118$ & $78 \pm 40$ & $156 \pm 72$ & $318 \pm 105$ & $553 \pm 289$ \\
\hline 1991-2012 & $\mathrm{x}$ & $85 \pm 41$ & $\mathrm{x}$ & $95 \pm 44$ & $37 \pm 25$ & $250 \pm 115$ & $\mathrm{x}$ & $\mathrm{x}$ & $153 \pm 73$ & $251 \pm 115$ & $72 \pm 35$ & $125 \pm 59$ & $318 \pm 110$ & $463 \pm 255$ \\
\hline 1981-2012 & $\mathrm{x}$ & $94 \pm 38$ & $\mathrm{x}$ & $120 \pm 48$ & $34 \pm 22$ & $238 \pm 106$ & $\mathrm{x}$ & $\mathrm{x}$ & $163 \pm 77$ & $259 \pm 118$ & $72 \pm 35$ & $117 \pm 57$ & $323 \pm 109$ & $\mathrm{x}$ \\
\hline 1971-2000 & $\mathrm{x}$ & $92 \pm 47$ & $\mathrm{x}$ & $117 \pm 50$ & $\mathrm{x}$ & $221 \pm 93$ & $\mathrm{x}$ & $\mathrm{x}$ & $165 \pm 73$ & $261 \pm 105$ & $62 \pm 32$ & $121 \pm 69$ & $345 \pm 133$ & $\mathrm{x}$ \\
\hline 1961-90 & $\mathrm{x}$ & $88 \pm 47$ & $\mathrm{x}$ & $107 \pm 52$ & $\mathrm{x}$ & $232 \pm 100$ & $248 \pm 104$ & $\mathrm{x}$ & $148 \pm 74$ & $225 \pm 102$ & $53 \pm 34$ & $135 \pm 75$ & $343 \pm 143$ & $\mathrm{x}$ \\
\hline 1951-80 & $50 \pm 25$ & $\mathrm{x}$ & $60 \pm 38$ & $\mathrm{x}$ & $\mathrm{x}$ & $210 \pm 109$ & $\mathrm{x}$ & $\mathrm{x}$ & $\mathrm{x}$ & $\mathrm{x}$ & $48 \pm 32$ & $132 \pm 77$ & $326 \pm 146$ & $\mathrm{x}$ \\
\hline $1941-70$ & $46 \pm 22$ & $\mathrm{x}$ & $61 \pm 42$ & $\mathrm{x}$ & $\mathrm{x}$ & $171 \pm 104$ & $\mathrm{x}$ & $\mathrm{x}$ & $\mathrm{x}$ & $\mathrm{x}$ & $\mathrm{x}$ & $\mathrm{x}$ & $275 \pm 125$ & $\mathrm{x}$ \\
\hline $1931-60$ & $47 \pm 22$ & $\mathrm{x}$ & $67 \pm 51$ & $\mathrm{x}$ & $\mathrm{x}$ & $111 \pm 62$ & $\mathrm{x}$ & $329 \pm 150$ & $\mathrm{x}$ & $\mathrm{x}$ & $\mathrm{x}$ & $\mathrm{x}$ & $238 \pm 104$ & $\mathrm{x}$ \\
\hline $1921-50$ & $69 \pm 40$ & $\mathrm{x}$ & $76 \pm 51$ & $\mathrm{x}$ & $\mathrm{x}$ & $108 \pm 70$ & $\mathrm{x}$ & $348 \pm 181$ & $\mathrm{x}$ & $\mathrm{x}$ & $\mathrm{x}$ & $\mathrm{x}$ & $229 \pm 101$ & $\mathrm{x}$ \\
\hline $1911-40$ & $70 \pm 37$ & $\mathrm{x}$ & $70 \pm 48$ & $\mathrm{x}$ & $\mathrm{x}$ & $93 \pm 66$ & $\mathrm{x}$ & $303 \pm 175$ & $\mathrm{x}$ & $\mathrm{x}$ & $\mathrm{x}$ & $\mathrm{x}$ & $221 \pm 96$ & $\mathrm{x}$ \\
\hline $1901-30$ & $61 \pm 39$ & $\mathrm{x}$ & $65 \pm 38$ & $\mathrm{x}$ & $\mathrm{x}$ & $114 \pm 78$ & $\mathrm{x}$ & $286 \pm 161$ & $\mathrm{x}$ & $\mathrm{x}$ & $\mathrm{x}$ & $\mathrm{x}$ & $255 \pm 111$ & $\mathrm{x}$ \\
\hline $1891-1920$ & $72 \pm 45$ & $\mathrm{x}$ & $56 \pm 38$ & $\mathrm{x}$ & $\mathrm{x}$ & $154 \pm 120$ & $\mathrm{x}$ & $366 \pm 161$ & $\mathrm{x}$ & $\mathrm{x}$ & $\mathrm{x}$ & $\mathrm{x}$ & $\mathrm{x}$ & $\mathrm{x}$ \\
\hline $1891-1910$ & $73 \pm 50$ & $\mathrm{x}$ & $47 \pm 24$ & $\mathrm{x}$ & $\mathrm{x}$ & $192 \pm 127$ & $\mathrm{x}$ & $333 \pm 184$ & $\mathrm{x}$ & $\mathrm{x}$ & $\mathrm{x}$ & $\mathrm{x}$ & $\mathrm{x}$ & $\mathrm{x}$ \\
\hline
\end{tabular}




\begin{tabular}{|c|c|c|c|c|c|c|c|c|c|c|c|c|c|c|}
\hline (c) Summer & Upernavik & Aasiaat & Ilulissat & Sisimiut & Kangerlussuaq & Nuuk & Paamiut & Ivittuut & Narsarsuaq & Qaqortoq & Danmarkshavn & Ittoqqortoormiit & Tasiilaq & Ikerasassuaq \\
\hline $2001-12$ & $\mathrm{x}$ & $143 \pm 49$ & $\mathrm{x}$ & $204 \pm 83$ & $101 \pm 30$ & $370 \pm 99$ & $\mathrm{x}$ & $\mathrm{x}$ & $200 \pm 73$ & $351 \pm 141$ & $51 \pm 33$ & $112 \pm 68$ & $157 \pm 82$ & $695 \pm 232$ \\
\hline 1991-2012 & $\mathrm{x}$ & $145 \pm 45$ & $\mathrm{x}$ & $215 \pm 83$ & $113 \pm 32$ & $360 \pm 100$ & $\mathrm{x}$ & $\mathrm{x}$ & $216 \pm 82$ & $349 \pm 130$ & $59 \pm 43$ & $117 \pm 60$ & $168 \pm 72$ & $630 \pm 239$ \\
\hline $1981-2012$ & $\mathrm{x}$ & $147 \pm 44$ & $\mathrm{x}$ & $232 \pm 66$ & $110 \pm 35$ & $361 \pm 106$ & $\mathrm{x}$ & $\mathrm{x}$ & $234 \pm 90$ & $358 \pm 129$ & $65 \pm 43$ & $121 \pm 64$ & $189 \pm 84$ & $\mathrm{x}$ \\
\hline $1971-2000$ & $\mathrm{x}$ & $145 \pm 52$ & $\mathrm{x}$ & $211 \pm 67$ & $\mathrm{x}$ & $357 \pm 101$ & $\mathrm{x}$ & $\mathrm{x}$ & $247 \pm 90$ & $352 \pm 122$ & $70 \pm 44$ & $130 \pm 65$ & $204 \pm 85$ & $\mathrm{x}$ \\
\hline $1961-90$ & $\mathrm{x}$ & $133 \pm 56$ & $\mathrm{x}$ & $195 \pm 67$ & $\mathrm{x}$ & $359 \pm 92$ & $348 \pm 121$ & $\mathrm{x}$ & $239 \pm 83$ & $351 \pm 115$ & $62 \pm 36$ & $145 \pm 78$ & $211 \pm 88$ & $\mathrm{x}$ \\
\hline $1951-80$ & $100 \pm 47$ & $\mathrm{x}$ & $\frac{\Lambda}{117 \pm 41}$ & $\mathrm{x}$ & $\mathrm{x}$ & $344 \pm 97$ & $\mathrm{x}$ & $\mathrm{x}$ & $\mathrm{x}$ & $\mathrm{x}$ & $51 \pm 27$ & $148 \pm 80$ & $184 \pm 76$ & $\mathrm{x}$ \\
\hline $1941-70$ & $93 \pm 48$ & $\mathrm{x}$ & $119 \pm 52$ & $\mathrm{x}$ & $\mathrm{x}$ & $298 \pm 127$ & $x$ & $\mathrm{x}$ & $\mathrm{x}$ & $\mathrm{x}$ & $\mathrm{x}$ & $\mathrm{x}$ & $177 \pm 70$ & $\mathrm{x}$ \\
\hline $1931-60$ & $82 \pm 40$ & $\mathrm{x}$ & $116 \pm 52$ & $\mathrm{x}$ & $\mathrm{x}$ & $273 \pm 132$ & $\mathrm{x}$ & $368 \pm 163$ & $\mathrm{x}$ & $\mathrm{x}$ & $\mathrm{x}$ & $\mathrm{x}$ & $171 \pm 64$ & $\mathrm{x}$ \\
\hline $1921-50$ & $97 \pm 42$ & $\begin{array}{l}\mathrm{A} \\
\mathrm{x}\end{array}$ & $115 \pm 53$ & $\begin{array}{l}\mathrm{A} \\
\mathrm{x}\end{array}$ & $\mathrm{x}$ & $264 \pm 122$ & $\begin{array}{l}\mathrm{A} \\
\mathrm{x}\end{array}$ & $367 \pm 167$ & $\mathrm{x}$ & $\mathrm{x}$ & $\mathrm{x}$ & $\mathrm{A}$ & $157 \pm 75$ & $\mathrm{x}$ \\
\hline 1911-40 & $99 \pm 41$ & $\mathrm{x}$ & $121 \pm 48$ & $\mathrm{x}$ & $\mathrm{x}$ & $287 \pm 122$ & $\mathrm{x}$ & $389 \pm 131$ & $\mathrm{x}$ & $\mathrm{x}$ & $\mathrm{x}$ & $\mathrm{x}$ & $173 \pm 92$ & $\mathrm{x}$ \\
\hline $1901-30$ & $109 \pm 51$ & $\mathrm{x}$ & $126 \pm 42$ & $\mathrm{x}$ & $\mathrm{x}$ & $254 \pm 137$ & $\mathrm{x}$ & $341 \pm 132$ & $\mathrm{x}$ & $\mathrm{x}$ & $\mathrm{x}$ & $\mathrm{x}$ & $184 \pm 108$ & $\mathrm{x}$ \\
\hline 1891-1920 & $101 \pm 52$ & $\mathrm{x}$ & $128 \pm 41$ & $\mathrm{x}$ & $\mathrm{x}$ & $254 \pm 149$ & $\mathrm{x}$ & $339 \pm 135$ & $\mathrm{x}$ & $\mathrm{x}$ & $\mathrm{x}$ & $\mathrm{x}$ & $\mathrm{x}$ & $\mathrm{x}$ \\
\hline $1891-1910$ & $103 \pm 56$ & $\mathrm{x}$ & $114 \pm 34$ & $\mathrm{x}$ & $\mathrm{x}$ & $238 \pm 147$ & $\mathrm{x}$ & $318 \pm 151$ & $\mathrm{x}$ & $\mathrm{x}$ & $\mathrm{x}$ & $\mathrm{x}$ & $\mathrm{x}$ & $\mathrm{x}$ \\
\hline
\end{tabular}

\begin{tabular}{|c|c|c|c|c|c|c|c|c|c|c|c|c|c|c|}
\hline (d) Autumn & Upernavik & Aasiaat & Ilulissat & Sisimiut & Kangerlussuaq & Nuuk & Paamiut & Ivittuut & Narsarsuaq & Qaqortoq & Danmarkshavn & Ittoqqortoormiit & Tasiilaq & Ikerasassuaq \\
\hline $2001-12$ & $\mathrm{x}$ & $184 \pm 74$ & $\mathrm{x}$ & $206 \pm 97$ & $74 \pm 32$ & $419 \pm 204$ & $\mathrm{x}$ & $\mathrm{x}$ & $260 \pm 174$ & $376 \pm 197$ & $56 \pm 20$ & $168 \pm 61$ & $320 \pm 117$ & $685 \pm 240$ \\
\hline 1991-2012 & $\mathrm{x}$ & $159 \pm 68$ & $\mathrm{x}$ & $193 \pm 87$ & $73 \pm 32$ & $391 \pm 164$ & $\mathrm{x}$ & $\mathrm{x}$ & $271 \pm 151$ & $409 \pm 187$ & $77 \pm 45$ & $190 \pm 67$ & $314 \pm 125$ & $700 \pm 287$ \\
\hline 1981-2012 & $\mathrm{x}$ & $161 \pm 62$ & $\mathrm{x}$ & $193 \pm 83$ & $69 \pm 30$ & $364 \pm 153$ & $\mathrm{x}$ & $\mathrm{x}$ & $254 \pm 152$ & $375 \pm 194$ & $72 \pm 41$ & $166 \pm 71$ & $334 \pm 120$ & $\mathrm{x}$ \\
\hline 1971-2000 & $\mathrm{x}$ & $158 \pm 54$ & $\mathrm{x}$ & $198 \pm 72$ & $\mathrm{x}$ & $334 \pm 109$ & $\mathrm{x}$ & $\mathrm{x}$ & $239 \pm 123$ & $354 \pm 174$ & $75 \pm 42$ & $188 \pm 102$ & $356 \pm 119$ & $\mathrm{x}$ \\
\hline $1961-90$ & $\mathrm{x}$ & $161 \pm 61$ & $\mathrm{x}$ & $195 \pm 71$ & $\mathrm{x}$ & $350 \pm 128$ & $321 \pm 104$ & $\mathrm{x}$ & $228 \pm 119$ & $322 \pm 156$ & $62 \pm 28$ & $189 \pm 108$ & $361 \pm 97$ & $\mathrm{x}$ \\
\hline $1951-80$ & $161 \pm 58$ & $\mathrm{x}$ & $132 \pm 60$ & $\mathrm{x}$ & $\mathrm{x}$ & $362 \pm 146$ & $\mathrm{x}$ & $\mathrm{x}$ & $\mathrm{x}$ & $\mathrm{x}$ & $68 \pm 41$ & $212 \pm 113$ & $370 \pm 118$ & $\mathrm{x}$ \\
\hline $1941-70$ & $153 \pm 60$ & $\mathrm{x}$ & $132 \pm 55$ & $\mathrm{x}$ & $\mathrm{x}$ & $329 \pm 153$ & $\mathrm{x}$ & $\mathrm{x}$ & $\mathrm{x}$ & $\mathrm{x}$ & $\mathrm{x}$ & $\mathrm{x}$ & $361 \pm 130$ & $\mathrm{x}$ \\
\hline $1931-60$ & $110 \pm 56$ & $\mathrm{x}$ & $130 \pm 47$ & $\mathrm{x}$ & $\mathrm{x}$ & $304 \pm 132$ & $\mathrm{x}$ & $639 \pm 209$ & $\mathrm{x}$ & $\mathrm{x}$ & $\mathrm{x}$ & $\mathrm{x}$ & $364 \pm 151$ & $\mathrm{x}$ \\
\hline $1921-50$ & $117 \pm 54$ & $\mathrm{x}$ & $122 \pm 36$ & $\mathrm{x}$ & $\mathrm{x}$ & $279 \pm 130$ & $\mathrm{x}$ & $622 \pm 213$ & $\mathrm{x}$ & $\mathrm{x}$ & $\mathrm{x}$ & $\mathrm{x}$ & $312 \pm 137$ & $\mathrm{x}$ \\
\hline $1911-40$ & $138 \pm 67$ & $\mathrm{x}$ & $116 \pm 32$ & $\mathrm{x}$ & $\mathrm{x}$ & $279 \pm 146$ & $\mathrm{x}$ & $608 \pm 223$ & $\mathrm{x}$ & $\mathrm{x}$ & $\mathrm{x}$ & $\mathrm{x}$ & $344 \pm 165$ & $\mathrm{x}$ \\
\hline $1901-30$ & $129 \pm 66$ & $\mathrm{x}$ & $121 \pm 42$ & $\mathrm{x}$ & $\mathrm{x}$ & $252 \pm 142$ & $\mathrm{x}$ & $532 \pm 174$ & $\mathrm{x}$ & $\mathrm{x}$ & $\mathrm{x}$ & $\mathrm{x}$ & $390 \pm 214$ & $\mathrm{x}$ \\
\hline $1891-1920$ & $146 \pm 81$ & $\mathrm{x}$ & $111 \pm 46$ & $\mathrm{x}$ & $\mathrm{x}$ & $265 \pm 151$ & $\mathrm{x}$ & $549 \pm 171$ & $\mathrm{x}$ & $\mathrm{x}$ & $\mathrm{x}$ & $\mathrm{x}$ & $\mathrm{x}$ & $\mathrm{x}$ \\
\hline $1891-1910$ & $133 \pm 83$ & $\mathrm{x}$ & $107 \pm 53$ & $\mathrm{x}$ & $\mathrm{x}$ & $276 \pm 150$ & $\mathrm{x}$ & $543 \pm 162$ & $\mathrm{x}$ & $\mathrm{x}$ & $\mathrm{x}$ & $\mathrm{x}$ & $\mathrm{x}$ & $\mathrm{x}$ \\
\hline
\end{tabular}




\begin{tabular}{|c|c|c|c|c|c|c|c|c|c|c|c|c|c|c|}
\hline (e) Winter & Upernavik & Aasiaat & Ilulissat & Sisimiut & Kangerlussuaq & Nuuk & Paamiut & Ivittuut & Narsarsuaq & Qaqortoq & Danmarkshavn & Ittoqqortoormiit & Tasiilaq & Ikerasassuaq \\
\hline $2001-12$ & $\mathrm{x}$ & $108 \pm 38$ & $\mathrm{x}$ & $139 \pm 66$ & $40 \pm 12$ & $286 \pm 130$ & $\mathrm{x}$ & $\mathrm{x}$ & $178 \pm 96$ & $287 \pm 166$ & $124 \pm 71$ & $213 \pm 121$ & $415 \pm 163$ & $635 \pm 230$ \\
\hline 1991-2012 & $\mathrm{x}$ & $105 \pm 35$ & $\mathrm{x}$ & $128 \pm 69$ & $36 \pm 15$ & $284 \pm 112$ & $\mathrm{x}$ & $\mathrm{x}$ & $178 \pm 104$ & $355 \pm 254$ & $113 \pm 60$ & $188 \pm 96$ & $453 \pm 213$ & $543 \pm 212$ \\
\hline 1981-2012 & $\mathrm{x}$ & $97 \pm 37$ & $\mathrm{x}$ & $105 \pm 61$ & $30 \pm 15$ & $254 \pm 115$ & $\mathrm{x}$ & $\mathrm{x}$ & $164 \pm 97$ & $313 \pm 224$ & $105 \pm 59$ & $172 \pm 97$ & $458 \pm 201$ & $\mathrm{x}$ \\
\hline 1971-2000 & $\mathrm{x}$ & $100 \pm 43$ & $\mathrm{x}$ & $87 \pm 40$ & $\mathrm{x}$ & $225 \pm 89$ & $\mathrm{x}$ & $\mathrm{x}$ & $165 \pm 109$ & $295 \pm 220$ & $87 \pm 47$ & $175 \pm 88$ & $528 \pm 222$ & $\mathrm{x}$ \\
\hline $1961-90$ & $\mathrm{x}$ & $92 \pm 46$ & $\mathrm{x}$ & $96 \pm 45$ & $\mathrm{x}$ & $217 \pm 89$ & $298 \pm 137$ & $\mathrm{x}$ & $169 \pm 107$ & $245 \pm 118$ & $69 \pm 43$ & $181 \pm 93$ & $497 \pm 210$ & $\mathrm{x}$ \\
\hline $1951-80$ & $64 \pm 28$ & $\mathrm{x}$ & $64 \pm 24$ & $\mathrm{x}$ & $\mathrm{x}$ & $235 \pm 128$ & $\mathrm{x}$ & $\mathrm{x}$ & $\mathrm{x}$ & $\mathrm{x}$ & $79 \pm 60$ & $190 \pm 84$ & $447 \pm 215$ & $\mathrm{x}$ \\
\hline $1941-70$ & $63 \pm 31$ & $\mathrm{x}$ & $65 \pm 41$ & $\mathrm{x}$ & $\mathrm{x}$ & $206 \pm 144$ & $\mathrm{x}$ & $\mathrm{x}$ & $\mathrm{x}$ & $\mathrm{x}$ & $\mathrm{x}$ & $\mathrm{x}$ & $321 \pm 155$ & $\mathrm{x}$ \\
\hline $1931-60$ & $51 \pm 27$ & $\mathrm{x}$ & $57 \pm 45$ & $\mathrm{x}$ & $\mathrm{x}$ & $144 \pm 139$ & $\mathrm{x}$ & $383 \pm 199$ & $\mathrm{x}$ & $\mathrm{x}$ & $\mathrm{x}$ & $\mathrm{x}$ & $303 \pm 149$ & $\mathrm{x}$ \\
\hline $1921-50$ & $64 \pm 37$ & $\mathrm{x}$ & $53 \pm 44$ & $\mathrm{x}$ & $\mathrm{x}$ & $80 \pm 50$ & $\mathrm{x}$ & $358 \pm 178$ & $\mathrm{x}$ & $\mathrm{x}$ & $\mathrm{x}$ & $\mathrm{x}$ & $294 \pm 151$ & $\mathrm{x}$ \\
\hline 1911-40 & $54 \pm 34$ & $\mathrm{x}$ & $47 \pm 29$ & $\mathrm{x}$ & $\mathrm{x}$ & $61 \pm 39$ & $\mathrm{x}$ & $312 \pm 195$ & $\mathrm{x}$ & $\mathrm{x}$ & $\mathrm{x}$ & $\mathrm{x}$ & $311 \pm 167$ & $\mathrm{x}$ \\
\hline $1901-30$ & $43 \pm 31$ & $\mathrm{x}$ & $49 \pm 23$ & $\mathrm{x}$ & $\mathrm{x}$ & $97 \pm 82$ & $\mathrm{x}$ & $259 \pm 138$ & $\mathrm{x}$ & $\mathrm{x}$ & $\mathrm{x}$ & $\mathrm{x}$ & $295 \pm 151$ & $\mathrm{x}$ \\
\hline 1891-1920 & $57 \pm 54$ & $\mathrm{x}$ & $41 \pm 27$ & $\mathrm{x}$ & $\mathrm{x}$ & $154 \pm 132$ & $\mathrm{x}$ & $271 \pm 175$ & $\mathrm{x}$ & $\mathrm{x}$ & $\mathrm{x}$ & $\mathrm{x}$ & $\mathrm{x}$ & $\mathrm{x}$ \\
\hline 1891-1910 & $65 \pm 63$ & $\mathrm{x}$ & $33 \pm 18$ & $\mathrm{x}$ & $\mathrm{x}$ & $210 \pm 134$ & $\mathrm{x}$ & $296 \pm 178$ & $\mathrm{x}$ & $\mathrm{x}$ & $\mathrm{x}$ & $\mathrm{x}$ & $\mathrm{x}$ & $\mathrm{x}$ \\
\hline
\end{tabular}


Table 4: Annual ice core estimated precipitation sum and standard deviations (mm w.e. $\mathrm{yr}^{-1}$ ) for climatological normal and shorter recent periods.

\begin{tabular}{|c|c|c|c|c|c|c|c|c|c|c|c|c|c|c|c|}
\hline Year & HumbMain & Nasau & GITS & D1 & D2 & D3 & D4 & D5 & $\begin{array}{l}\text { NEEM- } \\
\text { 2008-S3 }\end{array}$ & McBales & Act $2 d$ & Act 3 & $\begin{array}{c}\text { Summit } \\
2010\end{array}$ & $\begin{array}{c}\text { TUNU } \\
2013 \\
\end{array}$ & Act $11 d$ \\
\hline $2001-10$ & $\mathrm{x}$ & $\mathrm{x}$ & $\mathrm{x}$ & $\mathrm{x}$ & $\mathrm{x}$ & $\mathrm{x}$ & $\mathrm{x}$ & $\mathrm{x}$ & $\mathrm{x}$ & $\mathrm{x}$ & $\mathrm{x}$ & $\mathrm{x}$ & $243 \pm 54$ & $123 \pm 22$ & $378 \pm 64$ \\
\hline 1991-2010 & $\mathrm{x}$ & $\mathrm{x}$ & $\mathrm{x}$ & $\mathrm{x}$ & $\mathrm{x}$ & $\mathrm{x}$ & $\mathrm{x}$ & $\mathrm{x}$ & $\mathrm{x}$ & $\mathrm{x}$ & $\mathrm{x}$ & $\mathrm{x}$ & $248 \pm 46$ & $131 \pm 24$ & $421 \pm 82$ \\
\hline $1981-2010$ & $\mathrm{x}$ & $\mathrm{x}$ & $\mathrm{x}$ & $\mathrm{x}$ & $\mathrm{x}$ & $\mathrm{x}$ & $\mathrm{x}$ & $\mathrm{x}$ & $\mathrm{x}$ & $\mathrm{x}$ & $\mathrm{x}$ & $\mathrm{x}$ & $246 \pm 42$ & $131 \pm 23$ & $407 \pm 78$ \\
\hline $1971-2000$ & $\mathrm{x}$ & $\mathrm{x}$ & $\mathrm{x}$ & $823 \pm 139$ & $484 \pm 92$ & $440 \pm 80$ & $452 \pm 88$ & $415 \pm 87$ & $229 \pm 49$ & $240 \pm 38$ & $424 \pm 102$ & $741 \pm 131$ & $245 \pm 33$ & $129 \pm 24$ & $409 \pm 74$ \\
\hline $1961-90$ & $156 \pm 38$ & $380 \pm 80$ & $383 \pm 87$ & $791 \pm 150$ & $484 \pm 83$ & $449 \pm 73$ & $446 \pm 88$ & $408 \pm 75$ & $227 \pm 51$ & $237 \pm 31$ & $405 \pm 86$ & $720 \pm 143$ & $236 \pm 37$ & $124 \pm 23$ & $400 \pm 63$ \\
\hline $1951-80$ & $151 \pm 34$ & $390 \pm 73$ & $409 \pm 117$ & $803 \pm 153$ & $491 \pm 53$ & $460 \pm 73$ & $452 \pm 58$ & $411 \pm 81$ & $226 \pm 49$ & $239 \pm 40$ & $410 \pm 77$ & $725 \pm 137$ & $240 \pm 39$ & $122 \pm 20$ & $406 \pm 64$ \\
\hline $1941-70$ & $145 \pm 33$ & $381 \pm 76$ & $393 \pm 123$ & $811 \pm 185$ & $495 \pm 67$ & $485 \pm 74$ & $461 \pm 62$ & $417 \pm 68$ & $217 \pm 46$ & $244 \pm 40$ & $412 \pm 67$ & $735 \pm 125$ & $245 \pm 47$ & $125 \pm 21$ & $408 \pm 68$ \\
\hline $1931-60$ & $151 \pm 37$ & $376 \pm 84$ & $412 \pm 137$ & $856 \pm 188$ & $498 \pm 77$ & $491 \pm 81$ & $466 \pm 76$ & $426 \pm 71$ & $208 \pm 37$ & $250 \pm 41$ & $426 \pm 68$ & $754 \pm 122$ & $252 \pm 49$ & $128 \pm 25$ & $376 \pm 72$ \\
\hline $1921-50$ & $153 \pm 36$ & $365 \pm 88$ & $406 \pm 108$ & $897 \pm 203$ & $480 \pm 87$ & $472 \pm 78$ & $452 \pm 87$ & $403 \pm 77$ & $209 \pm 38$ & $240 \pm 43$ & $421 \pm 70$ & $764 \pm 134$ & $243 \pm 49$ & $121 \pm 26$ & $360 \pm 66$ \\
\hline $1911-40$ & $152 \pm 37$ & $363 \pm 97$ & $414 \pm 105$ & $862 \pm 184$ & $483 \pm 93$ & $472 \pm 86$ & $450 \pm 89$ & $403 \pm 82$ & $219 \pm 48$ & $234 \pm 46$ & $411 \pm 77$ & $742 \pm 119$ & $240 \pm 49$ & $127 \pm 31$ & $349 \pm 64$ \\
\hline $1901-30$ & $162 \pm 49$ & $353 \pm 95$ & $368 \pm 89$ & $824 \pm 181$ & $478 \pm 88$ & $464 \pm 85$ & $446 \pm 80$ & $382 \pm 78$ & $216 \pm 46$ & $223 \pm 58$ & $407 \pm 65$ & $722 \pm 114$ & $236 \pm 46$ & $119 \pm 27$ & $348 \pm 59$ \\
\hline $1891-1920$ & $156 \pm 49$ & $364 \pm 96$ & $388 \pm 98$ & $801 \pm 197$ & $499 \pm 84$ & $490 \pm 81$ & $460 \pm 77$ & $400 \pm 72$ & $213 \pm 52$ & $234 \pm 55$ & $404 \pm 62$ & $716 \pm 132$ & $244 \pm 49$ & $121 \pm 27$ & $359 \pm 67$ \\
\hline $1891-1910$ & $168 \pm 53$ & $363 \pm 93$ & $393 \pm 104$ & $804 \pm 217$ & $497 \pm 75$ & $490 \pm 71$ & $459 \pm 77$ & $397 \pm 75$ & $204 \pm 45$ & $238 \pm 60$ & $410 \pm 56$ & $706 \pm 152$ & $243 \pm 47$ & $112 \pm 17$ & $362 \pm 68$ \\
\hline
\end{tabular}


Table 5: (a) Greenland coastal annual precipitation; (b) spring (MAM); (c) summer (JJA); (d) autumn (SON); and (e) winter trends (DJF) (mm w.e. $\left.\mathrm{yr}^{-2}\right)$ for climatological normal and shorter recent periods. Significant trends $(p<0.05)$ are highlighted in bold type.

\begin{tabular}{|c|c|c|c|c|c|c|c|c|c|c|c|c|c|c|}
\hline (a) Year & Upernavik & Aasiaat & Ilulissat & Sisimiut & Kangerlussuaq & Nuuk & Paamiut & Ivittuut & Narsarsuaq & Qaqortoq & Danmarkshavn & Ittoqqortoormiit & Tasiilaq & Ikerasassuaq \\
\hline $2001-12$ & $\mathrm{x}$ & 25.1 & $\mathrm{x}$ & 48.5 & -2.8 & -7.6 & $\mathrm{x}$ & $\mathrm{x}$ & 1.8 & -29.7 & 4.9 & 1.0 & -53.9 & 24.8 \\
\hline 1991-2012 & $\mathrm{x}$ & 11.0 & $\mathrm{x}$ & 20.5 & 0.6 & 14.4 & $\mathrm{x}$ & $\mathrm{x}$ & -6.1 & -24.6 & -3.5 & 3.8 & -17.3 & 16.5 \\
\hline 1981-2012 & $\mathrm{x}$ & 3.2 & $\mathrm{x}$ & 0.7 & 1.9 & 12.9 & $\mathrm{x}$ & $\mathrm{x}$ & -1.2 & 0.1 & -0.1 & 4.5 & -10.9 & $\mathrm{x}$ \\
\hline 1971-2000 & $\mathrm{x}$ & -1.0 & $\mathrm{x}$ & 5.5 & $\mathrm{x}$ & 3.8 & $\mathrm{x}$ & $\mathrm{x}$ & 5.0 & 19.7 & 3.6 & -11.1 & -16.7 & $\mathrm{x}$ \\
\hline 1961-90 & $\mathrm{x}$ & 6.5 & $\mathrm{x}$ & 6.5 & $\mathrm{x}$ & -8.6 & 6.0 & $\mathrm{x}$ & 3.3 & 1.4 & 4.8 & -9.8 & 5.8 & $\mathrm{x}$ \\
\hline 1951-80 & 4.9 & $\mathrm{x}$ & 4.1 & $\mathrm{x}$ & $\mathrm{x}$ & 8.3 & $\mathrm{x}$ & $\mathrm{x}$ & $\mathrm{x}$ & $\mathrm{x}$ & -0.1 & 7.2 & 22.8 & $\mathrm{x}$ \\
\hline $1941-70$ & 6.7 & $\mathrm{x}$ & -2.7 & $\mathrm{x}$ & $\mathrm{x}$ & 23.8 & $\mathrm{x}$ & $\mathrm{x}$ & $\mathrm{x}$ & $\mathrm{x}$ & $\mathrm{x}$ & $\mathrm{x}$ & 11.3 & $\mathrm{x}$ \\
\hline $1931-60$ & 0.7 & $\mathrm{x}$ & 1.0 & $\mathrm{x}$ & $\mathrm{x}$ & 5.5 & $\mathrm{x}$ & -22.3 & $\mathrm{x}$ & $\mathrm{x}$ & $\mathrm{x}$ & $\mathrm{x}$ & 5.1 & $\mathrm{x}$ \\
\hline $1921-50$ & -11.0 & $\mathrm{x}$ & 5.2 & $\mathrm{x}$ & $\mathrm{x}$ & -5.1 & $\mathrm{x}$ & 9.3 & $\mathrm{x}$ & $\mathrm{x}$ & $\mathrm{x}$ & $\mathrm{x}$ & 2.3 & $\mathrm{x}$ \\
\hline $1911-40$ & 0.7 & $\mathrm{x}$ & -4.3 & $\mathrm{x}$ & $\mathrm{x}$ & 3.6 & $\mathrm{x}$ & 24.3 & $\mathrm{x}$ & $\mathrm{x}$ & $\mathrm{x}$ & $\mathrm{x}$ & -7.2 & $\mathrm{x}$ \\
\hline $1901-30$ & 6.0 & $\mathrm{x}$ & -1.2 & $\mathrm{x}$ & $\mathrm{x}$ & -4.6 & $\mathrm{x}$ & -3.5 & $\mathrm{x}$ & $\mathrm{x}$ & $\mathrm{x}$ & $\mathrm{x}$ & -22.5 & $\mathrm{x}$ \\
\hline 1891-1920 & -4.7 & $\mathrm{x}$ & 6.8 & $\mathrm{x}$ & $\mathrm{x}$ & -22.0 & $\mathrm{x}$ & -12.7 & $\mathrm{x}$ & $\mathrm{x}$ & $\mathrm{x}$ & $\mathrm{x}$ & $\mathrm{x}$ & $\mathrm{x}$ \\
\hline $1891-1910$ & -23.4 & $\mathrm{x}$ & 7.7 & $\mathrm{x}$ & $\mathrm{x}$ & -25.6 & $\mathrm{x}$ & -16.9 & $\mathrm{x}$ & $\mathrm{x}$ & $\mathrm{x}$ & $\mathrm{x}$ & $\mathrm{x}$ & $\mathrm{x}$ \\
\hline
\end{tabular}

\begin{tabular}{|c|c|c|c|c|c|c|c|c|c|c|c|c|c|c|}
\hline (b) Spring & Upernavik & Aasiaat & Ilulissat & Sisimiut & Kangerlussuaq & Nuuk & Paamiut & Ivittuut & Narsarsuaq & Qaqortoq & Danmarkshavn & Ittoqqortoormiit & Tasiilaq & Ikerasassuaq \\
\hline $2001-12$ & $\mathrm{x}$ & 5.4 & $\mathrm{x}$ & 8.4 & -1.6 & 6.8 & $\mathrm{x}$ & $\mathrm{x}$ & 4.5 & 8.2 & 3.8 & 8.1 & -2.1 & 23.2 \\
\hline 1991-2012 & $\mathrm{x}$ & 3.8 & $\mathrm{x}$ & 2.6 & 1.0 & 7.0 & $\mathrm{x}$ & $\mathrm{x}$ & -1.6 & -3.3 & 1.2 & 5.5 & -0.5 & 23.5 \\
\hline 1981-2012 & $\mathrm{x}$ & -0.8 & $\mathrm{x}$ & -1.3 & 0.7 & 4.1 & $\mathrm{x}$ & $\mathrm{x}$ & -1.9 & -2.4 & 0.5 & 2.4 & -1.1 & $\mathrm{x}$ \\
\hline $1971-2000$ & $\mathrm{x}$ & -0.7 & $\mathrm{x}$ & 1.3 & $\mathrm{x}$ & 0.6 & $\mathrm{x}$ & $\mathrm{x}$ & 1.9 & 2.9 & 0.8 & -3.5 & -3.2 & $\mathrm{x}$ \\
\hline 1961-90 & $\mathrm{x}$ & 2.8 & $\mathrm{x}$ & 3.0 & $\mathrm{x}$ & -0.6 & 5.2 & $\mathrm{x}$ & 2.5 & 4.0 & 1.8 & -1.7 & -0.5 & $\mathrm{x}$ \\
\hline 1951-80 & 0.6 & $\mathrm{x}$ & 1.9 & $\mathrm{x}$ & $\mathrm{x}$ & 5.7 & $\mathrm{x}$ & $\mathrm{x}$ & $\mathrm{x}$ & $\mathrm{x}$ & 0.3 & 3.8 & 5.3 & $\mathrm{x}$ \\
\hline 1941-70 & -0.5 & $\mathrm{x}$ & -1.5 & $\mathrm{x}$ & $\mathrm{x}$ & 6.1 & $\mathrm{x}$ & $\mathrm{x}$ & $\mathrm{x}$ & $\mathrm{x}$ & $\mathrm{x}$ & $\mathrm{x}$ & 4.3 & $\mathrm{x}$ \\
\hline $1931-60$ & -0.4 & $\mathrm{x}$ & -0.6 & $\mathrm{x}$ & $\mathrm{x}$ & 1.5 & $\mathrm{x}$ & -3.3 & $\mathrm{x}$ & $\mathrm{x}$ & $\mathrm{x}$ & $\mathrm{x}$ & 4.8 & $\mathrm{x}$ \\
\hline $1921-50$ & -2.8 & $\mathrm{x}$ & 1.1 & $\mathrm{x}$ & $\mathrm{x}$ & -0.6 & $\mathrm{x}$ & 4.7 & $\mathrm{x}$ & $\mathrm{x}$ & $\mathrm{x}$ & $\mathrm{x}$ & -1.2 & $\mathrm{x}$ \\
\hline 1911-40 & -0.5 & $\mathrm{x}$ & -0.6 & $\mathrm{x}$ & $\mathrm{x}$ & 0.1 & $\mathrm{x}$ & 4.5 & $\mathrm{x}$ & $\mathrm{x}$ & $\mathrm{x}$ & $\mathrm{x}$ & 0.1 & $\mathrm{x}$ \\
\hline 1901-30 & 2.2 & $\mathrm{x}$ & 0.9 & $\mathrm{x}$ & $\mathrm{x}$ & -1.3 & $\mathrm{x}$ & 0.2 & $\mathrm{x}$ & $\mathrm{x}$ & $\mathrm{x}$ & $\mathrm{x}$ & -2.6 & $\mathrm{x}$ \\
\hline $1891-1920$ & -1.5 & $\mathrm{x}$ & 1.4 & $\mathrm{x}$ & $\mathrm{x}$ & -10.3 & $\mathrm{x}$ & -6.4 & $\mathrm{x}$ & $\mathrm{x}$ & $\mathrm{x}$ & $\mathrm{x}$ & $\mathrm{x}$ & $\mathrm{x}$ \\
\hline $1891-1910$ & -5.8 & $\mathrm{x}$ & 0.9 & $\mathrm{x}$ & $\mathrm{x}$ & -10.7 & $\mathrm{x}$ & -6.9 & $\mathrm{x}$ & $\mathrm{x}$ & $\mathrm{x}$ & $\mathrm{x}$ & $\mathrm{x}$ & $\mathrm{x}$ \\
\hline
\end{tabular}




\begin{tabular}{|c|c|c|c|c|c|c|c|c|c|c|c|c|c|c|}
\hline (c) Summer & Upernavik & Aasiaat & Ilulissat & Sisimiut & Kangerlussuaq & Nuuk & Paamiut & Ivittuut & Narsarsuaq & Qaqortoq & Danmarkshavn & Ittoqqortoormiit & Tasiilaq & Ikerasassuaq \\
\hline $2001-12$ & $\mathrm{x}$ & 6.5 & $\mathrm{x}$ & 11.7 & 0.4 & -4.5 & $\mathrm{x}$ & $\mathrm{x}$ & -4.3 & -23.0 & -1.7 & 1.7 & -7.4 & 11.0 \\
\hline $1991-2012$ & $\mathrm{x}$ & 1.0 & $\mathrm{x}$ & 0.8 & -2.3 & 1.9 & $\mathrm{x}$ & $\mathrm{x}$ & -2.5 & -2.6 & -1.2 & -1.0 & -2.6 & 12.3 \\
\hline 1981-2012 & $\mathrm{x}$ & 0.3 & $\mathrm{x}$ & -1.6 & -0.5 & -0.3 & $\mathrm{x}$ & $\mathrm{x}$ & -3.2 & -2.3 & -1.3 & -0.7 & -4.0 & $\mathrm{x}$ \\
\hline 1971-2000 & $\mathrm{x}$ & 0.7 & $\mathrm{x}$ & 4.9 & $\mathrm{x}$ & -0.8 & $\mathrm{x}$ & $\mathrm{x}$ & 0.0 & 0.4 & 0.2 & -1.1 & -0.8 & $\mathrm{x}$ \\
\hline $1961-90$ & $\mathrm{x}$ & 2.2 & $\mathrm{x}$ & 3.2 & $\mathrm{x}$ & -0.4 & 3.8 & $\mathrm{x}$ & 2.4 & 0.5 & 1.2 & -1.7 & 1.4 & $\mathrm{x}$ \\
\hline 1951-80 & 1.4 & $\mathrm{x}$ & 1.6 & $\mathrm{x}$ & $\mathrm{x}$ & 1.9 & $\mathrm{x}$ & $\mathrm{x}$ & $\mathrm{x}$ & $\mathrm{x}$ & 0.8 & -0.5 & 2.4 & $\mathrm{x}$ \\
\hline $1941-70$ & 0.9 & $\mathrm{x}$ & -1.0 & $\mathrm{x}$ & $\mathrm{x}$ & 4.8 & $\mathrm{x}$ & $\mathrm{x}$ & $\mathrm{x}$ & $\mathrm{x}$ & $\mathrm{x}$ & $\mathrm{x}$ & 1.2 & $\mathrm{x}$ \\
\hline $1931-60$ & -0.7 & $\mathrm{x}$ & -0.6 & $\mathrm{x}$ & $\mathrm{x}$ & 1.9 & $\mathrm{x}$ & -2.9 & $\mathrm{x}$ & $\mathrm{x}$ & $\mathrm{x}$ & $\mathrm{x}$ & -1.4 & $\mathrm{x}$ \\
\hline 1921-50 & -1.6 & $\mathrm{x}$ & 1.6 & $\mathrm{x}$ & $\mathrm{x}$ & -3.0 & $\mathrm{x}$ & -0.4 & $\mathrm{x}$ & $\mathrm{x}$ & $\mathrm{x}$ & $\mathrm{x}$ & 2.6 & $\mathrm{x}$ \\
\hline 1911-40 & -0.7 & $\mathrm{x}$ & -2.1 & $\mathrm{x}$ & $\mathrm{x}$ & 0.8 & $\mathrm{x}$ & 2.8 & $\mathrm{x}$ & $\mathrm{x}$ & $\mathrm{x}$ & $\mathrm{x}$ & -2.2 & $\mathrm{x}$ \\
\hline $1901-30$ & -0.7 & $\mathrm{x}$ & -1.0 & $\mathrm{x}$ & $\mathrm{x}$ & 4.2 & $\mathrm{x}$ & -0.8 & $\mathrm{x}$ & $\mathrm{x}$ & $\mathrm{x}$ & $\mathrm{x}$ & -5.1 & $\mathrm{x}$ \\
\hline $1891-1920$ & 0.6 & $\mathrm{x}$ & 2.4 & $\mathrm{x}$ & $\mathrm{x}$ & -3.6 & $\mathrm{x}$ & 1.3 & $\mathrm{x}$ & $\mathrm{x}$ & $\mathrm{x}$ & $\mathrm{x}$ & $\mathrm{x}$ & $\mathrm{x}$ \\
\hline 1891-1910 & 3.0 & $\mathrm{x}$ & 1.5 & $\mathrm{x}$ & $\mathrm{x}$ & -15.1 & $\mathrm{x}$ & -5.5 & $\mathrm{x}$ & $\mathrm{x}$ & $\mathrm{x}$ & $\mathrm{x}$ & $\mathrm{x}$ & $\mathrm{x}$ \\
\hline
\end{tabular}

\begin{tabular}{|c|c|c|c|c|c|c|c|c|c|c|c|c|c|c|}
\hline (d) Autumn & Upernavik & Aasiaat & Ilulissat & Sisimiut & Kangerlussuaq & Nuuk & Paamiut & Ivittuut & Narsarsuaq & Qaqortoq & Danmarkshavn & Ittoqqortoormiit & Tasiilaq & Ikerasassuaq \\
\hline $2001-12$ & $\mathrm{x}$ & 11.0 & $\mathrm{x}$ & 12.2 & -0.5 & -1.1 & $\mathrm{x}$ & $\mathrm{x}$ & -2.3 & -12.9 & 1.4 & -4.3 & -13.3 & -2.6 \\
\hline 1991-2012 & $\mathrm{x}$ & 5.5 & $\mathrm{x}$ & 6.0 & 0.2 & 4.4 & $\mathrm{x}$ & $\mathrm{x}$ & -3.4 & -8.1 & -3.8 & -3.8 & -3.2 & -8.6 \\
\hline 1981-2012 & $\mathrm{x}$ & 1.7 & $\mathrm{x}$ & 1.4 & 0.7 & 5.5 & $\mathrm{x}$ & $\mathrm{x}$ & 2.1 & 3.1 & -0.5 & 2.4 & -3.0 & $\mathrm{x}$ \\
\hline $1971-2000$ & $\mathrm{x}$ & -1.3 & $\mathrm{x}$ & -2.3 & $\mathrm{x}$ & 1.1 & $\mathrm{x}$ & $\mathrm{x}$ & 3.3 & 6.3 & 1.8 & -1.0 & -3.7 & $\mathrm{x}$ \\
\hline $1961-90$ & $\mathrm{x}$ & 1.0 & $\mathrm{x}$ & 0.7 & $\mathrm{x}$ & -4.7 & -0.6 & $\mathrm{x}$ & -0.1 & 0.7 & -0.2 & -4.1 & 3.1 & $\mathrm{x}$ \\
\hline 1951-80 & 1.7 & $\mathrm{x}$ & 0.3 & $\mathrm{x}$ & $\mathrm{x}$ & -0.4 & $\mathrm{x}$ & $\mathrm{x}$ & $\mathrm{x}$ & $\mathrm{x}$ & -0.6 & 1.7 & -0.1 & $\mathrm{x}$ \\
\hline 1941-70 & 2.6 & $\mathrm{x}$ & -0.2 & $\mathrm{x}$ & $\mathrm{x}$ & 5.9 & $\mathrm{x}$ & $\mathrm{x}$ & $\mathrm{x}$ & $\mathrm{x}$ & $\mathrm{x}$ & $\mathrm{x}$ & -1.3 & $\mathrm{x}$ \\
\hline 1931-60 & 1.6 & $\mathrm{x}$ & 0.6 & $\mathrm{x}$ & $\mathrm{x}$ & -0.5 & $\mathrm{x}$ & -9.6 & $\mathrm{x}$ & $\mathrm{x}$ & $\mathrm{x}$ & $\mathrm{x}$ & 3.8 & $\mathrm{x}$ \\
\hline 1921-50 & -4.8 & $\mathrm{x}$ & 0.6 & $\mathrm{x}$ & $\mathrm{x}$ & -1.8 & $\mathrm{x}$ & 4.1 & $\mathrm{x}$ & $\mathrm{x}$ & $\mathrm{x}$ & $\mathrm{x}$ & 3.3 & $\mathrm{x}$ \\
\hline 1911-40 & -3.0 & $\mathrm{x}$ & -0.3 & $\mathrm{x}$ & $\mathrm{x}$ & 3.0 & $\mathrm{x}$ & 8.4 & $\mathrm{x}$ & $\mathrm{x}$ & $\mathrm{x}$ & $\mathrm{x}$ & -6.1 & $\mathrm{x}$ \\
\hline 1901-30 & 3.5 & $\mathrm{x}$ & -1.1 & $\mathrm{x}$ & $\mathrm{x}$ & -1.1 & $\mathrm{x}$ & -3.1 & $\mathrm{x}$ & $\mathrm{x}$ & $\mathrm{x}$ & $\mathrm{x}$ & -11.9 & $\mathrm{x}$ \\
\hline 1891-1920 & -0.6 & $\mathrm{x}$ & 1.4 & $\mathrm{x}$ & $\mathrm{x}$ & -2.3 & $\mathrm{x}$ & 1.7 & $\mathrm{x}$ & $\mathrm{x}$ & $\mathrm{x}$ & $\mathrm{x}$ & $\mathrm{x}$ & $\mathrm{x}$ \\
\hline 1891-1910 & -11.1 & $\mathrm{x}$ & 3.6 & $\mathrm{x}$ & $\mathrm{x}$ & 0.6 & $\mathrm{x}$ & 6.5 & $\mathrm{x}$ & $\mathrm{x}$ & $\mathrm{x}$ & $\mathrm{x}$ & $\mathrm{x}$ & $\mathrm{x}$ \\
\hline
\end{tabular}

\begin{tabular}{|c|c|c|c|c|c|c|c|c|c|c|c|c|c|c|}
\hline (e) Winter & Upernavik & Aasiaat & Ilulissat & Sisimiut & Kangerlussuaq & Nuuk & Paamiut & Ivittuut & Narsarsuaq & Qaqortoq & Danmarkshavn & Ittoqqortoormiit & Tasiilaq & Ikerasassuaq \\
\hline $2001-12$ & $\mathrm{x}$ & -0.4 & $\mathrm{x}$ & 7.2 & -0.3 & -14.2 & $\mathrm{x}$ & $\mathrm{x}$ & -1.3 & 0.10 & 1.9 & 17.3 & -35.9 & -21.3 \\
\hline 1991-2012 & $\mathrm{x}$ & 0.7 & $\mathrm{x}$ & 6.4 & 0.9 & -0.9 & $\mathrm{x}$ & $\mathrm{x}$ & -1.6 & -10.2 & 1.1 & 6.1 & -15.0 & 13.2 \\
\hline
\end{tabular}




\begin{tabular}{|c|c|c|c|c|c|c|c|c|c|c|c|c|c|c|}
\hline 1981-2012 & $\mathrm{x}$ & 1.4 & $\mathrm{x}$ & 2.7 & 1.0 & 3.1 & $\mathrm{x}$ & $\mathrm{x}$ & 1.1 & 2.4 & 1.7 & 2.9 & -5.5 & $\mathrm{x}$ \\
\hline $1971-2000$ & $\mathrm{x}$ & 0.0 & $\mathrm{x}$ & -0.5 & $\mathrm{x}$ & 3.4 & $\mathrm{x}$ & $\mathrm{x}$ & -0.6 & 10.0 & 1.3 & -3.4 & -7.6 & $\mathbf{x}$ \\
\hline 1961-90 & $\mathrm{x}$ & 0.7 & $\mathrm{x}$ & -0.9 & $\mathrm{x}$ & -3.2 & -3.2 & $\mathrm{x}$ & -2.0 & -2.5 & 2.1 & -2.8 & 1.5 & $\mathrm{x}$ \\
\hline $1951-80$ & 1.1 & $\mathrm{x}$ & 1.0 & $\mathrm{x}$ & $\mathrm{x}$ & -2.9 & $\mathrm{x}$ & $\mathrm{x}$ & $\mathrm{x}$ & $\mathrm{x}$ & -1.8 & 2.1 & 12.7 & $\mathrm{x}$ \\
\hline $1941-70$ & 2.9 & $\mathrm{x}$ & -0.2 & $\mathrm{x}$ & $\mathrm{x}$ & 5.1 & $\mathrm{x}$ & $\mathrm{x}$ & $\mathrm{x}$ & $\mathrm{x}$ & $\mathrm{x}$ & $\mathrm{x}$ & 7.0 & $\mathrm{x}$ \\
\hline $1931-60$ & -0.7 & $\mathrm{x}$ & 1.4 & $\mathrm{x}$ & $\mathrm{x}$ & 6.7 & $\mathrm{x}$ & -5.8 & $\mathrm{x}$ & $\mathrm{x}$ & $\mathrm{x}$ & $\mathrm{x}$ & -2.3 & $\mathrm{x}$ \\
\hline $1921-50$ & -2.1 & $\mathrm{x}$ & 1.7 & $\mathrm{x}$ & $\mathrm{x}$ & 2.9 & $\mathrm{x}$ & -0.0 & $\mathrm{x}$ & $\mathrm{x}$ & $\mathrm{x}$ & $\mathrm{x}$ & -4.1 & $\mathrm{x}$ \\
\hline $1911-40$ & 1.1 & $\mathrm{x}$ & -0.8 & $\mathrm{x}$ & $\mathrm{x}$ & 1.0 & $\mathrm{x}$ & 7.4 & $\mathrm{x}$ & $\mathrm{x}$ & $\mathrm{x}$ & $\mathrm{x}$ & -0.3 & $\mathrm{x}$ \\
\hline $1901-30$ & 1.8 & $\mathrm{x}$ & 0.3 & $\mathrm{x}$ & $\mathrm{x}$ & -5.1 & $\mathrm{x}$ & 1.3 & $\mathrm{x}$ & $\mathrm{x}$ & $\mathrm{x}$ & $\mathrm{x}$ & -2.5 & $\mathrm{x}$ \\
\hline $1891-1920$ & -2.7 & $\mathrm{x}$ & 1.7 & $\mathrm{x}$ & $\mathrm{x}$ & -10.5 & $\mathrm{x}$ & -4.4 & $\mathrm{x}$ & $\mathrm{x}$ & $\mathrm{x}$ & $\mathrm{x}$ & $\mathrm{x}$ & $\mathrm{x}$ \\
\hline $1891-1910$ & $\begin{array}{l}-6.1 \\
\end{array}$ & $\mathrm{x}$ & 1.5 & $\mathrm{x}$ & $\mathrm{x}$ & -6.5 & $\mathrm{x}$ & -5.1 & $\mathrm{x}$ & $\mathrm{x}$ & $\mathrm{x}$ & $\mathrm{x}$ & $\mathrm{x}$ & $\mathrm{x}$ \\
\hline
\end{tabular}


Table 6: Greenland Ice Sheet ice core estimated annual precipitation ( $\mathrm{mm}$ w.e. $\mathrm{yr}^{-2}$ ) for climatological normal and shorter recent periods. Significant trends $(p<0.05)$ are highlighted in bold type.

\begin{tabular}{|c|c|c|c|c|c|c|c|c|c|c|c|c|c|c|c|}
\hline Year & HumbMain & Nasau & GITS & D1 & D2 & D3 & D4 & D5 & $\begin{array}{l}\text { NEEM- } \\
\text { 2008-S3 }\end{array}$ & McBales & Act $2 d$ & Act 3 & $\begin{array}{c}\text { Summit } \\
2010\end{array}$ & $\begin{array}{l}\text { TUNU } \\
2013\end{array}$ & Act $11 \mathrm{~d}$ \\
\hline $2001-10$ & $\mathrm{x}$ & $\mathrm{x}$ & $\mathrm{x}$ & $\mathrm{x}$ & $\mathrm{x}$ & $\mathrm{x}$ & $\mathrm{x}$ & $\mathrm{x}$ & $\mathrm{x}$ & $\mathrm{x}$ & $\mathrm{x}$ & $\mathrm{x}$ & -7.3 & 0.8 & -15.4 \\
\hline 1991-2010 & $\mathrm{x}$ & $\mathrm{x}$ & $\mathrm{x}$ & $\mathrm{x}$ & $\mathrm{x}$ & $\mathrm{x}$ & $\mathrm{x}$ & $\mathrm{x}$ & $\mathrm{x}$ & $\mathrm{x}$ & $\mathrm{x}$ & $\mathrm{x}$ & -1.1 & -0.6 & -7.9 \\
\hline 1981-2010 & $\mathrm{x}$ & $\mathrm{x}$ & $\mathrm{x}$ & $\mathrm{x}$ & $\mathrm{x}$ & $\mathrm{x}$ & $\mathrm{x}$ & $\mathrm{x}$ & $\mathrm{x}$ & $\mathrm{x}$ & $\mathrm{x}$ & $\mathrm{x}$ & 0.1 & -0.1 & -0.2 \\
\hline 1971-2000 & $\mathrm{x}$ & $\mathrm{x}$ & $\mathrm{x}$ & -1.3 & 1.1 & 1.4 & 1.3 & 2.1 & 0.1 & 0.8 & 0.4 & -1.0 & 0.7 & 1.2 & 3.9 \\
\hline $1961-90$ & 1.2 & -2.2 & -4.2 & 1.0 & -0.7 & -0.2 & -0.4 & 0.2 & -1.3 & -0.3 & 0.2 & 2.3 & 0.3 & 0.5 & -1.9 \\
\hline $1951-80$ & -0.5 & 0.9 & -1.0 & 3.8 & -0.8 & -3.8 & -1.0 & -2.4 & -0.2 & -1.1 & -0.6 & 1.7 & -0.8 & -0.5 & -1.0 \\
\hline $1941-70$ & 0.0 & 1.0 & 2.4 & -7.0 & -0.5 & -1.7 & -1.2 & 0.0 & 0.8 & -0.8 & -1.9 & -6.6 & -1.7 & -0.1 & 2.8 \\
\hline $1931-60$ & -0.7 & -0.4 & -3.8 & -2.9 & -1.4 & -0.6 & -0.9 & -0.7 & 0.3 & -1.0 & -0.5 & 1.6 & -0.3 & -0.2 & 3.4 \\
\hline $1921-50$ & -1.2 & 1.4 & -0.8 & -1.5 & 1.7 & 1.7 & 2.2 & 1.6 & -0.5 & 1.2 & 0.8 & 2.6 & 1.0 & 0.8 & 3.1 \\
\hline $1911-40$ & 0.9 & 0.8 & 4.6 & 3.6 & -0.1 & -0.5 & 0.4 & 1.4 & -1.1 & 1.6 & 2.4 & 0.8 & -0.1 & -0.1 & 0.7 \\
\hline $1901-30$ & -1.2 & -1.0 & 2.3 & 6.6 & -2.2 & -1.4 & -1.8 & -0.4 & 0.8 & 0.4 & -0.2 & 4.5 & -0.7 & 0.1 & 1.0 \\
\hline $1891-1920$ & -0.1 & -1.5 & -3.7 & -3.1 & -0.9 & -1.7 & -1.1 & -0.8 & 0.2 & -0.5 & -0.1 & -0.1 & -0.6 & 1.3 & -0.8 \\
\hline 1891-1910 & 5.3 & -4.9 & -8.9 & -8.5 & -3.8 & $\begin{array}{l}-5.4 \\
\end{array}$ & -3.8 & -3.7 & -2.5 & -0.9 & 1.1 & -2.8 & -1.8 & 0.1 & -2.8 \\
\hline
\end{tabular}


Table 7: Monthly, seasonal, and yearly driest and wettest precipitation sums at coastal DMI Greenland climate stations (mm w.e. $\left.\mathrm{yr}^{-1}\right)$. Driest and wettest records since 2000 are highlighted in bold. In case the monthly precipitation is zero for two or more months, the latest year of occurrence is mentioned in brackets.

\begin{tabular}{|c|c|c|c|c|c|c|c|c|c|c|c|c|c|c|c|c|c|c|}
\hline Station & & Jan & Feb & Mar & Apr & May & Jun & Jul & Aug & Sep & Oct & Nov & Dec & $\begin{array}{l}\text { Spring } \\
\text { (MAM) }\end{array}$ & $\begin{array}{c}\text { Summer } \\
\text { (JJA) }\end{array}$ & $\begin{array}{c}\text { Autumn } \\
\text { (SON) }\end{array}$ & $\begin{array}{l}\text { Winter } \\
\text { (DJF) }\end{array}$ & Year \\
\hline \multirow{2}{*}{$\begin{array}{c}\text { Upernavik } \\
\text { (Jan 1890-Dec } 1980\end{array}$} & driest & $\begin{array}{c}0.0 \\
(1937)\end{array}$ & $\begin{array}{c}0.0 \\
(1937)\end{array}$ & $\begin{array}{c}0.0 \\
(1935)\end{array}$ & $\begin{array}{c}0.0 \\
(1904)\end{array}$ & $\begin{array}{c}0.0 \\
(1933)\end{array}$ & $\begin{array}{c}0.0 \\
(1939)\end{array}$ & $\begin{array}{c}0.0 \\
(1935)\end{array}$ & $\begin{array}{c}0.0 \\
(1941)\end{array}$ & $\begin{array}{c}0.0 \\
(1935)\end{array}$ & $\begin{array}{c}2.5 \\
(1908)\end{array}$ & $\begin{array}{c}1.4 \\
(1910)\end{array}$ & $\begin{array}{c}0.0 \\
(1908)\end{array}$ & $\begin{array}{c}2.0 \\
(1890)\end{array}$ & $\begin{array}{c}20.2 \\
(1957)\end{array}$ & $\begin{array}{c}14.7 \\
(1935)\end{array}$ & $\begin{array}{c}5.3 \\
(1912 / 13)\end{array}$ & \begin{tabular}{|l|}
133.8 \\
$(1911)$ \\
\end{tabular} \\
\hline & wettest & $\begin{array}{c}82.4 \\
(1979) \\
\end{array}$ & $\begin{array}{c}142.3 \\
(1901)\end{array}$ & $\begin{array}{c}98.2 \\
(1900)\end{array}$ & $\begin{array}{c}105.4 \\
(1978)\end{array}$ & $\begin{array}{c}96.5 \\
(1895) \\
\end{array}$ & $\begin{array}{c}112.4 \\
(1916)\end{array}$ & $\begin{array}{l}204.1 \\
(1908)\end{array}$ & $\begin{array}{c}162.8 \\
(1907) \\
\end{array}$ & $\begin{array}{l}156.6 \\
(1967) \\
\end{array}$ & $\begin{array}{c}149.1 \\
(1899)\end{array}$ & $\begin{array}{c}176.2 \\
(1969) \\
\end{array}$ & $\begin{array}{c}87.4 \\
(1893) \\
\end{array}$ & $\begin{array}{l}178.0 \\
(1896) \\
\end{array}$ & $\begin{array}{l}254.5 \\
(1908) \\
\end{array}$ & $\begin{array}{l}310.9 \\
(1895)\end{array}$ & $\begin{array}{c}233.5 \\
(1896 / 97) \\
\end{array}$ & $\begin{array}{l}700.6 \\
(1895) \\
\end{array}$ \\
\hline \multirow{2}{*}{$\begin{array}{c}\text { Aasiaat } \\
\text { (Jan 1958-present) }\end{array}$} & driest & $\begin{array}{c}1.4 \\
(1959) \\
\end{array}$ & $\begin{array}{c}2.7 \\
(1963) \\
\end{array}$ & $\begin{array}{c}0.0 \\
(1960) \\
\end{array}$ & $\begin{array}{c}2.8 \\
(1961) \\
\end{array}$ & $\begin{array}{c}1.6 \\
(\mathbf{2 0 0 4}) \\
\end{array}$ & $\begin{array}{c}0.0 \\
(1990) \\
\end{array}$ & $\begin{array}{c}0.0 \\
(\mathbf{2 0 0 8}) \\
\end{array}$ & $\begin{array}{c}0.0 \\
(1966) \\
\end{array}$ & $\begin{array}{c}3.0 \\
(1988) \\
\end{array}$ & $\begin{array}{c}9.4 \\
(\mathbf{2 0 0 2}) \\
\end{array}$ & $\begin{array}{c}10.1 \\
(1968) \\
\end{array}$ & $\begin{array}{c}8.4 \\
(1962) \\
\end{array}$ & $\begin{array}{c}15.3 \\
(1960) \\
\end{array}$ & $\begin{array}{c}35.3 \\
(1969) \\
\end{array}$ & $\begin{array}{c}65.1 \\
(1994) \\
\end{array}$ & $\begin{array}{c}18.6 \\
(1958 / 59) \\
\end{array}$ & $\begin{array}{c}22.3 \\
(1965) \\
\end{array}$ \\
\hline & wettest & $\begin{array}{l}112.8 \\
(1979)\end{array}$ & $\begin{array}{l}104.5 \\
(1969) \\
\end{array}$ & $\begin{array}{l}150.0 \\
(1979) \\
\end{array}$ & $\begin{array}{c}116.4 \\
(1973)\end{array}$ & $\begin{array}{c}91.7 \\
(1980)\end{array}$ & $\begin{array}{l}177.4 \\
(1974)\end{array}$ & $\begin{array}{l}189.4 \\
(1959)\end{array}$ & $\begin{array}{l}189.4 \\
(1986)\end{array}$ & $\begin{array}{c}200.1 \\
(1961)\end{array}$ & $\begin{array}{l}144.5 \\
(1978)\end{array}$ & $\begin{array}{l}144.3 \\
(1985) \\
\end{array}$ & $\begin{array}{c}91.4 \\
(1977)\end{array}$ & $\begin{array}{l}200.9 \\
(1979) \\
\end{array}$ & $\begin{array}{l}283.8 \\
(1959) \\
\end{array}$ & $\begin{array}{l}288.0 \\
(\mathbf{2 0 1 2})\end{array}$ & $\begin{array}{c}197.5 \\
(1978 / 79) \\
\end{array}$ & \begin{tabular}{|l|}
755.4 \\
$(\mathbf{2 0 1 2})$ \\
\end{tabular} \\
\hline \multirow{2}{*}{$\begin{array}{c}\text { Illulissat } \\
\text { (Jan 1890-Dec 1984) }\end{array}$} & driest & $\begin{array}{c}0.3 \\
(1925)\end{array}$ & $\begin{array}{c}0.0 \\
(1939)\end{array}$ & $\begin{array}{c}0.4 \\
(1934) \\
\end{array}$ & $\begin{array}{c}0.9 \\
(1898)\end{array}$ & $\begin{array}{c}0.0 \\
(1934)\end{array}$ & $\begin{array}{c}0.0 \\
(1937)\end{array}$ & $\begin{array}{c}0.6 \\
(1957)\end{array}$ & $\begin{array}{c}0.0 \\
(1966)\end{array}$ & $\begin{array}{c}4.8 \\
(1930)\end{array}$ & $\begin{array}{c}2.7 \\
(1940)\end{array}$ & $\begin{array}{c}1.1 \\
(1939)\end{array}$ & $\begin{array}{c}1.9 \\
(1898)\end{array}$ & $\begin{array}{c}8.2 \\
(1920) \\
\end{array}$ & $\begin{array}{c}21.5 \\
(1943) \\
\end{array}$ & $\begin{array}{c}29.7 \\
(1891)\end{array}$ & $\begin{array}{c}6.6 \\
(1898 / 99)\end{array}$ & $\begin{array}{c}185.3 \\
(1896) \\
\end{array}$ \\
\hline & wettest & $\begin{array}{c}62.7 \\
(1949) \\
\end{array}$ & $\begin{array}{c}95.7 \\
(1948) \\
\end{array}$ & $\begin{array}{c}72.8 \\
(1949) \\
\end{array}$ & $\begin{array}{l}152.9 \\
(1973) \\
\end{array}$ & $\begin{array}{c}97.9 \\
(1948) \\
\end{array}$ & $\begin{array}{l}133.2 \\
(1942) \\
\end{array}$ & $\begin{array}{l}144.8 \\
(1944) \\
\end{array}$ & $\begin{array}{c}171.7 \\
(1935) \\
\end{array}$ & $\begin{array}{c}230.4 \\
(1967) \\
\end{array}$ & $\begin{array}{l}141.0 \\
(1978) \\
\end{array}$ & $\begin{array}{l}114.6 \\
(1969) \\
\end{array}$ & $\begin{array}{c}104.7 \\
(1940) \\
\end{array}$ & $\begin{array}{r}212.9 \\
(1973) \\
\end{array}$ & $\begin{array}{l}238.0 \\
(1942) \\
\end{array}$ & $\begin{array}{c}285.9 \\
(1957) \\
\end{array}$ & $\begin{array}{c}208.2 \\
(1948 / 49) \\
\end{array}$ & \begin{tabular}{|l|}
742.7 \\
$(1948)$ \\
\end{tabular} \\
\hline \multirow{2}{*}{$\begin{array}{c}\text { Sisimiut } \\
\text { (Jan 1961-present, } \\
\text { minus 1993-2001 } \\
\text { and 2004-2008) } \\
\end{array}$} & driest & $\begin{array}{c}2.9 \\
(1966) \\
\end{array}$ & $\begin{array}{c}1.7 \\
(1985) \\
\end{array}$ & $\begin{array}{c}1.9 \\
(1992) \\
\end{array}$ & $\begin{array}{c}0.8 \\
(1963) \\
\end{array}$ & $\begin{array}{c}0.6 \\
(1963) \\
\end{array}$ & $\begin{array}{c}5.4 \\
(1973) \\
\end{array}$ & $\begin{array}{c}7.9 \\
(1976) \\
\end{array}$ & $\begin{array}{c}0.5 \\
(1977) \\
\end{array}$ & $\begin{array}{c}12.4 \\
(1988) \\
\end{array}$ & $\begin{array}{c}12.2 \\
(1971) \\
\end{array}$ & $\begin{array}{c}9.4 \\
(1968) \\
\end{array}$ & $\begin{array}{c}0.0 \\
(1991) \\
\end{array}$ & $\begin{array}{c}7.4 \\
(1963) \\
\end{array}$ & $\begin{array}{c}93.9 \\
(1980) \\
\end{array}$ & $\begin{array}{c}81.5 \\
(1982) \\
\end{array}$ & $\begin{array}{c}15.5 \\
(1989 / 90) \\
\end{array}$ & \begin{tabular}{|l|}
260.5 \\
$(1992)$ \\
\end{tabular} \\
\hline & wettest & $\begin{array}{c}106.7 \\
(\mathbf{2 0 1 0}) \\
\end{array}$ & $\begin{array}{l}123.0 \\
(1988) \\
\end{array}$ & $\begin{array}{c}94.5 \\
(1987) \\
\end{array}$ & $\begin{array}{l}175.0 \\
(1973) \\
\end{array}$ & $\begin{array}{l}114.8 \\
(1982) \\
\end{array}$ & $\begin{array}{l}170.2 \\
(\mathbf{2 0 0 4}) \\
\end{array}$ & $\begin{array}{l}166.6 \\
(1972) \\
\end{array}$ & $\begin{array}{l}211.7 \\
(1986) \\
\end{array}$ & $\begin{array}{l}299.5 \\
(1976) \\
\end{array}$ & $\begin{array}{l}147.3 \\
(1972) \\
\end{array}$ & $\begin{array}{l}142.5 \\
(1971) \\
\end{array}$ & $\begin{array}{r}173.3 \\
(\mathbf{2 0 1 0}) \\
\end{array}$ & $\begin{array}{l}215.5 \\
(1973) \\
\end{array}$ & $\begin{array}{l}321.0 \\
(1981) \\
\end{array}$ & $\begin{array}{l}389.1 \\
(1986) \\
\end{array}$ & $\begin{array}{c}223.9 \\
(1969 / 70) \\
\end{array}$ & \begin{tabular}{|l|}
1003.8 \\
$(\mathbf{2 0 1 2})$ \\
\end{tabular} \\
\hline \multirow{2}{*}{$\begin{array}{c}\text { Kangerlussuaq } \\
\text { (Jan 1976-present) }\end{array}$} & driest & $\begin{array}{c}0.6 \\
(1990) \\
\end{array}$ & $\begin{array}{c}0.4 \\
(1989) \\
\end{array}$ & $\begin{array}{c}0.0 \\
(\mathbf{2 0 0 6}) \\
\end{array}$ & $\begin{array}{c}0.0 \\
(\mathbf{2 0 1 1}) \\
\end{array}$ & $\begin{array}{c}0.0 \\
(1995) \\
\end{array}$ & $\begin{array}{c}0.0 \\
(\mathbf{2 0 0 0}) \\
\end{array}$ & $\begin{array}{c}2.9 \\
(1999) \\
\end{array}$ & $\begin{array}{c}0.0 \\
(1977) \\
\end{array}$ & $\begin{array}{c}4.2 \\
(1995) \\
\end{array}$ & $\begin{array}{c}2.8 \\
(1985) \\
\end{array}$ & $\begin{array}{c}1.5 \\
(\mathbf{2 0 0 6}) \\
\end{array}$ & $\begin{array}{c}0.0 \\
(1985) \\
\end{array}$ & $\begin{array}{c}2.9 \\
(1995) \\
\end{array}$ & $\begin{array}{c}27.2 \\
(1980) \\
\end{array}$ & $\begin{array}{c}32.1 \\
(1995) \\
\end{array}$ & $\begin{array}{c}5.7 \\
(1989 / 90) \\
\end{array}$ & \begin{tabular}{|l}
111.3 \\
$(1980)$ \\
\end{tabular} \\
\hline & wettest & $\begin{array}{c}33.6 \\
(\mathbf{2 0 1 0})\end{array}$ & $\begin{array}{c}32.1 \\
(\mathbf{2 0 1 1})\end{array}$ & $\begin{array}{c}15.5 \\
(1991) \\
\end{array}$ & $\begin{array}{c}55.4 \\
(\mathbf{2 0 0 5}) \\
\end{array}$ & $\begin{array}{c}46.7 \\
(\mathbf{2 0 0 5}) \\
\end{array}$ & $\begin{array}{c}58.5 \\
(1994) \\
\end{array}$ & $\begin{array}{c}92.4 \\
(1997) \\
\end{array}$ & $\begin{array}{c}117.3 \\
(1991) \\
\end{array}$ & $\begin{array}{c}91.9 \\
(\mathbf{2 0 0 3})\end{array}$ & $\begin{array}{c}59.2 \\
(1978) \\
\end{array}$ & $\begin{array}{c}59.8 \\
(\mathbf{2 0 0 1}) \\
\end{array}$ & $\begin{array}{c}32.1 \\
(\mathbf{2 0 0 6})\end{array}$ & $\begin{array}{l}105.0 \\
(\mathbf{2 0 0 5}) \\
\end{array}$ & $\begin{array}{l}195.9 \\
(1983) \\
\end{array}$ & $\begin{array}{c}137.1 \\
(\mathbf{2 0 0 0})\end{array}$ & $\begin{array}{c}61.3 \\
(\mathbf{2 0 0 3 / 0 4}) \\
\end{array}$ & \begin{tabular}{|l|}
330.0 \\
$(1997)$ \\
\end{tabular} \\
\hline
\end{tabular}




\begin{tabular}{|c|c|c|c|c|c|c|c|c|c|c|c|c|c|c|c|c|c|c|}
\hline \multirow{2}{*}{$\begin{array}{c}\text { Nuuk } \\
\text { (Jan 1890-present) }\end{array}$} & driest & $\begin{array}{c}3.9 \\
(1939)\end{array}$ & $\begin{array}{c}0.0 \\
(1933)\end{array}$ & $\begin{array}{c}0.0 \\
(1909)\end{array}$ & $\begin{array}{c}0.0 \\
(1902) \\
\end{array}$ & $\begin{array}{c}0.0 \\
(1911) \\
\end{array}$ & $\begin{array}{c}0.0 \\
(1913)\end{array}$ & $\begin{array}{c}0.0 \\
(1933)\end{array}$ & $\begin{array}{c}0.0 \\
(1966)\end{array}$ & $\begin{array}{c}1.7 \\
(1948)\end{array}$ & $\begin{array}{c}6.2 \\
(1917)\end{array}$ & $\begin{array}{c}4.9 \\
(1931) \\
\end{array}$ & $\begin{array}{c}0.2 \\
(1946) \\
\end{array}$ & $\begin{array}{c}16.5 \\
(1930) \\
\end{array}$ & $\begin{array}{c}13.9 \\
(1903) \\
\end{array}$ & $\begin{array}{c}56.7 \\
(1951) \\
\end{array}$ & $\begin{array}{c}19.0 \\
(1939 / 40)\end{array}$ & $\begin{array}{c}367.1 \\
(1948) \\
\end{array}$ \\
\hline & wettest & $\begin{array}{l}365.7 \\
(1953) \\
\end{array}$ & $\begin{array}{c}387.7 \\
(1890) \\
\end{array}$ & $\begin{array}{c}416.1 \\
(1968)\end{array}$ & $\begin{array}{l}246.6 \\
(\mathbf{2 0 0 6})\end{array}$ & $\begin{array}{l}395.1 \\
(1928) \\
\end{array}$ & $\begin{array}{l}257.7 \\
(1979)\end{array}$ & $\begin{array}{r}350.7 \\
(1983) \\
\end{array}$ & $\begin{array}{l}334.2 \\
(1984) \\
\end{array}$ & $\begin{array}{r}341.5 \\
(1967) \\
\end{array}$ & $\begin{array}{l}460.0 \\
(1995) \\
\end{array}$ & $\begin{array}{l}373.4 \\
(\mathbf{2 0 0 8}) \\
\end{array}$ & $\begin{array}{l}231.8 \\
(\mathbf{2 0 0 1})\end{array}$ & $\begin{array}{l}568.8 \\
(\mathbf{2 0 0 5}) \\
\end{array}$ & $\begin{array}{l}614.4 \\
(1915) \\
\end{array}$ & $\begin{array}{l}840.8 \\
(\mathbf{2 0 0 8}) \\
\end{array}$ & $\begin{array}{c}613.9 \\
1953 / 54 \\
\end{array}$ & \begin{tabular}{|l|}
1881.9 \\
$(\mathbf{2 0 0 5})$ \\
\end{tabular} \\
\hline \multirow{2}{*}{$\begin{array}{c}\text { Paamiut } \\
\text { (Jan 1958-Aug } \\
\text { 1992) }\end{array}$} & driest & $\begin{array}{c}1.8 \\
(1966)\end{array}$ & $\begin{array}{c}9.8 \\
(1982)\end{array}$ & $\begin{array}{c}8.9 \\
(1962)\end{array}$ & $\begin{array}{c}4.9 \\
(1961)\end{array}$ & $\begin{array}{c}6.0 \\
(1968)\end{array}$ & $\begin{array}{c}7.7 \\
(1974)\end{array}$ & $\begin{array}{c}1.6 \\
(1992)\end{array}$ & $\begin{array}{c}0.0 \\
(1858)\end{array}$ & $\begin{array}{c}34.2 \\
(1968)\end{array}$ & $\begin{array}{c}4.9 \\
(1968)\end{array}$ & $\begin{array}{c}25.3 \\
(1974)\end{array}$ & $\begin{array}{c}6.2 \\
(1978)\end{array}$ & $\begin{array}{c}84.4 \\
(1985)\end{array}$ & $\begin{array}{l}122.1 \\
(1958)\end{array}$ & $\begin{array}{c}96.7 \\
(1968)\end{array}$ & $\begin{array}{c}70.8 \\
(1959 / 60)\end{array}$ & $\begin{array}{l}689.5 \\
(1958)\end{array}$ \\
\hline & wettest & $\begin{array}{l}282.8 \\
(1967)\end{array}$ & $\begin{array}{c}278.4 \\
(1965)\end{array}$ & $\begin{array}{c}214.1 \\
(1968)\end{array}$ & $\begin{array}{c}196.2 \\
(1983) \\
\end{array}$ & $\begin{array}{l}296.1 \\
(1987)\end{array}$ & $\begin{array}{c}214.1 \\
(1983)\end{array}$ & $\begin{array}{c}276.2 \\
(1964) \\
\end{array}$ & $\begin{array}{l}487.8 \\
(1984) \\
\end{array}$ & $\begin{array}{r}259.7 \\
(1989) \\
\end{array}$ & $\begin{array}{r}250.5 \\
(1972) \\
\end{array}$ & $\begin{array}{c}246.2 \\
(1983) \\
\end{array}$ & $\begin{array}{c}408.4 \\
(1975)\end{array}$ & $\begin{array}{c}480.1 \\
(1983)\end{array}$ & $\begin{array}{c}690.5 \\
(1983) \\
\end{array}$ & $\begin{array}{l}495.1 \\
(1966)\end{array}$ & $\begin{array}{c}661.2 \\
(1975 / 76) \\
\end{array}$ & \begin{tabular}{|l|}
1997.1 \\
$(1983)$ \\
\end{tabular} \\
\hline \multirow{2}{*}{$\begin{array}{c}\text { Ivittuut } \\
\text { (Jan 1890-Dec 1960) }\end{array}$} & driest & $\begin{array}{c}1.8 \\
(1940)\end{array}$ & $\begin{array}{c}0.0 \\
(1912)\end{array}$ & $\begin{array}{c}0.7 \\
(1897)\end{array}$ & $\begin{array}{c}1.2 \\
(1937)\end{array}$ & $\begin{array}{c}0.0 \\
(1930)\end{array}$ & $\begin{array}{c}1.9 \\
(1916)\end{array}$ & $\begin{array}{c}2.3 \\
(1933) \\
\end{array}$ & $\begin{array}{c}0.0 \\
(1958)\end{array}$ & $\begin{array}{c}31.4 \\
(1930)\end{array}$ & $\begin{array}{c}31.3 \\
(1903) \\
\end{array}$ & $\begin{array}{c}3.1 \\
(1910)\end{array}$ & $\begin{array}{c}0.0 \\
(1924)\end{array}$ & $\begin{array}{c}75.4 \\
(1904) \\
\end{array}$ & $\begin{array}{c}26.6 \\
(1903)\end{array}$ & $\begin{array}{l}232.9 \\
(1920)\end{array}$ & $\begin{array}{c}32.3 \\
(1911 / 12) \\
\end{array}$ & \begin{tabular}{|l|}
758.6 \\
$(1924)$ \\
\end{tabular} \\
\hline & wettest & $\begin{array}{l}484.0 \\
(1891)\end{array}$ & $\begin{array}{l}607.5 \\
(1932) \\
\end{array}$ & $\begin{array}{l}520.9 \\
1891 \\
\end{array}$ & $\begin{array}{l}297.7 \\
(1938)\end{array}$ & $\begin{array}{l}398.0 \\
(1903)\end{array}$ & $\begin{array}{l}396.5 \\
(1934) \\
\end{array}$ & $\begin{array}{c}358.1 \\
(1945) \\
\end{array}$ & $\begin{array}{l}354.2 \\
(1915) \\
\end{array}$ & $\begin{array}{c}513.7 \\
(1939) \\
\end{array}$ & $\begin{array}{c}508.0 \\
(1944) \\
\end{array}$ & $\begin{array}{l}431.4 \\
(1933) \\
\end{array}$ & $\begin{array}{l}272.1 \\
(1952)\end{array}$ & $\begin{array}{l}826.7 \\
(1929) \\
\end{array}$ & $\begin{array}{c}669.1 \\
(1937) \\
\end{array}$ & $\begin{array}{l}1042.4 \\
(1937) \\
\end{array}$ & $\begin{array}{c}875.0 \\
(1933 / 34) \\
\end{array}$ & \begin{tabular}{|l|}
2433.0 \\
$(1945)$ \\
\end{tabular} \\
\hline \multirow{2}{*}{$\begin{array}{c}\text { Narsarsuaq } \\
\text { (Jan 1961-present) }\end{array}$} & driest & $\begin{array}{c}0.3 \\
(1966) \\
\end{array}$ & $\begin{array}{c}0.4 \\
(\mathbf{2 0 1 0}) \\
\end{array}$ & $\begin{array}{c}0.0 \\
(1962)\end{array}$ & $\begin{array}{c}2.4 \\
(1989) \\
\end{array}$ & $\begin{array}{c}3.6 \\
(1974) \\
\end{array}$ & $\begin{array}{c}0.3 \\
(\mathbf{2 0 0 8}) \\
\end{array}$ & $\begin{array}{c}0.3 \\
(1992) \\
\end{array}$ & $\begin{array}{c}0.6 \\
(1966) \\
\end{array}$ & $\begin{array}{c}5.2 \\
(1981) \\
\end{array}$ & $\begin{array}{c}0.0 \\
(1968) \\
\end{array}$ & $\begin{array}{c}2.8 \\
(\mathbf{2 0 0 2}) \\
\end{array}$ & $\begin{array}{c}4.2 \\
(\mathbf{2 0 0 0})\end{array}$ & $\begin{array}{c}32.3 \\
(1962) \\
\end{array}$ & $\begin{array}{c}90.0 \\
(\mathbf{2 0 0 9}) \\
\end{array}$ & $\begin{array}{c}24.2 \\
(1968) \\
\end{array}$ & $\begin{array}{c}18.6 \\
(1965 / 66) \\
\end{array}$ & \begin{tabular}{|l|}
330.1 \\
$(1985)$ \\
\end{tabular} \\
\hline & wettest & $\begin{array}{l}214.0 \\
(1996)\end{array}$ & $\begin{array}{c}334.3 \\
(1993) \\
\end{array}$ & $\begin{array}{c}165.7 \\
(1998)\end{array}$ & $\begin{array}{c}170.2 \\
(1999)\end{array}$ & $\begin{array}{l}204.4 \\
(1987)\end{array}$ & $\begin{array}{l}170.7 \\
(1983) \\
\end{array}$ & $\begin{array}{l}290.6 \\
(1966) \\
\end{array}$ & $\begin{array}{l}278.4 \\
(1984)\end{array}$ & $\begin{array}{l}289.4 \\
(1990) \\
\end{array}$ & $\begin{array}{l}242.1 \\
(2003)\end{array}$ & $\begin{array}{l}401.5 \\
(\mathbf{2 0 0 8})\end{array}$ & $\begin{array}{c}418.1 \\
(1975)\end{array}$ & $\begin{array}{l}298.1 \\
(\mathbf{2 0 1 2})\end{array}$ & $\begin{array}{c}454.1 \\
(1983)\end{array}$ & $\begin{array}{l}616.0 \\
(\mathbf{2 0 0 8})\end{array}$ & $\begin{array}{c}491.5 \\
(1975 / 76) \\
\end{array}$ & $\begin{array}{l}1336.3 \\
(1983) \\
\end{array}$ \\
\hline \multirow{2}{*}{$\begin{array}{c}\text { Qaqortoq } \\
\text { (Jan 1961-present) }\end{array}$} & driest & $\begin{array}{c}5.7 \\
(1966) \\
\end{array}$ & $\begin{array}{c}0.7 \\
(1982) \\
\end{array}$ & $\begin{array}{c}0.0 \\
(1962) \\
\end{array}$ & $\begin{array}{c}1.7 \\
(1989) \\
\end{array}$ & $\begin{array}{c}3.5 \\
(1985) \\
\end{array}$ & $\begin{array}{c}2.7 \\
(\mathbf{2 0 1 0}) \\
\end{array}$ & $\begin{array}{c}4.1 \\
(1992) \\
\end{array}$ & $\begin{array}{c}5.7 \\
(1980) \\
\end{array}$ & $\begin{array}{c}2.1 \\
(1981) \\
\end{array}$ & $\begin{array}{c}0.8 \\
(1968) \\
\end{array}$ & $\begin{array}{c}4.0 \\
(\mathbf{2 0 0 2}) \\
\end{array}$ & $\begin{array}{c}9.3 \\
(\mathbf{2 0 0 7}) \\
\end{array}$ & $\begin{array}{c}47.1 \\
(1985) \\
\end{array}$ & $\begin{array}{l}131.2 \\
(1992) \\
\end{array}$ & $\begin{array}{c}41.3 \\
(1968) \\
\end{array}$ & $\begin{array}{c}43.0 \\
(1965 / 66) \\
\end{array}$ & \begin{tabular}{|c|}
530.8 \\
$(1985)$ \\
\end{tabular} \\
\hline & wettest & $\begin{array}{l}279.3 \\
(1967) \\
\end{array}$ & $\begin{array}{l}333.7 \\
(1993) \\
\end{array}$ & $\begin{array}{l}281.1 \\
(1983) \\
\end{array}$ & $\begin{array}{l}235.8 \\
(1975) \\
\end{array}$ & $\begin{array}{l}225.5 \\
(1987) \\
\end{array}$ & $\begin{array}{l}192.5 \\
(1997) \\
\end{array}$ & $\begin{array}{l}496.0 \\
(1966) \\
\end{array}$ & $\begin{array}{l}342.8 \\
(1984) \\
\end{array}$ & $\begin{array}{c}311.6 \\
(1990) \\
\end{array}$ & $\begin{array}{c}285.4 \\
(1987) \\
\end{array}$ & $\begin{array}{l}386.2 \\
(\mathbf{2 0 0 1}) \\
\end{array}$ & $\begin{array}{c}987.4 \\
(1998) \\
\end{array}$ & $\begin{array}{l}533.7 \\
(1983) \\
\end{array}$ & $\begin{array}{l}560.8 \\
(1984) \\
\end{array}$ & $\begin{array}{l}739.3 \\
(1995) \\
\end{array}$ & $\begin{array}{c}1223.4 \\
(1998 / 99) \\
\end{array}$ & \begin{tabular}{|l|}
1972.1 \\
$(\mathbf{2 0 1 2})$ \\
\end{tabular} \\
\hline \multirow{2}{*}{$\begin{array}{c}\text { Danmarkshavn } \\
\text { (Jan 1949-present) }\end{array}$} & driest & $\begin{array}{c}1.2 \\
(1975)\end{array}$ & $\begin{array}{c}0.0 \\
(\mathbf{2 0 1 0})\end{array}$ & $\begin{array}{c}0.2 \\
(1962)\end{array}$ & $\begin{array}{c}0.0 \\
(1962)\end{array}$ & $\begin{array}{c}0.0 \\
(1997)\end{array}$ & $\begin{array}{c}0.0 \\
(\mathbf{2 0 1 2})\end{array}$ & $\begin{array}{c}0.0 \\
(\mathbf{2 0 1 0})\end{array}$ & $\begin{array}{c}0.2 \\
(1973)\end{array}$ & $\begin{array}{c}0.0 \\
(1962)\end{array}$ & $\begin{array}{c}0.3 \\
(1960)\end{array}$ & $\begin{array}{c}0.0 \\
(1952)\end{array}$ & $\begin{array}{c}0.0 \\
(1952)\end{array}$ & $\begin{array}{c}4.5 \\
(1962)\end{array}$ & $\begin{array}{c}7.3 \\
(\mathbf{2 0 1 0})\end{array}$ & $\begin{array}{c}6.8 \\
(1951)\end{array}$ & $\begin{array}{c}6.8 \\
(1950 / 51)\end{array}$ & $\begin{array}{c}63.1 \\
(1951)\end{array}$ \\
\hline & wettest & $\begin{array}{l}161.5 \\
(\mathbf{2 0 0 6}) \\
\end{array}$ & $\begin{array}{c}82.0 \\
(\mathbf{2 0 0 8}) \\
\end{array}$ & $\begin{array}{c}106.7 \\
(\mathbf{2 0 1 2}) \\
\end{array}$ & $\begin{array}{c}82.4 \\
(\mathbf{2 0 0 6}) \\
\end{array}$ & $\begin{array}{c}34.4 \\
(\mathbf{2 0 0 9})\end{array}$ & $\begin{array}{c}57.2 \\
(1954) \\
\end{array}$ & $\begin{array}{c}86.6 \\
(1986) \\
\end{array}$ & $\begin{array}{l}110.7 \\
(1990) \\
\end{array}$ & $\begin{array}{c}182.1 \\
(1955) \\
\end{array}$ & $\begin{array}{c}99.8 \\
(1957) \\
\end{array}$ & $\begin{array}{c}141.3 \\
(1991) \\
\end{array}$ & $\begin{array}{l}108.8 \\
(1957) \\
\end{array}$ & $\begin{array}{l}147.9 \\
(\mathbf{2 0 1 1}) \\
\end{array}$ & $\begin{array}{l}161.1 \\
(1998) \\
\end{array}$ & $\begin{array}{c}244.4 \\
(1991) \\
\end{array}$ & $\begin{array}{c}289.2 \\
(\mathbf{2 0 0 5 / 0 6}) \\
\end{array}$ & \begin{tabular}{|c|}
536.9 \\
$(1990)$ \\
\end{tabular} \\
\hline \multirow{2}{*}{$\begin{array}{l}\text { Ittoqqortoormiit } \\
\text { (Jan 1950-present) }\end{array}$} & driest & $\begin{array}{c}3.3 \\
(1955)\end{array}$ & $\begin{array}{c}1.2 \\
(1965)\end{array}$ & $\begin{array}{c}6.4 \\
(1992)\end{array}$ & $\begin{array}{c}0.1 \\
(1988)\end{array}$ & $\begin{array}{c}0.0 \\
(1958)\end{array}$ & $\begin{array}{c}0.0 \\
(1982)\end{array}$ & $\begin{array}{c}0.0 \\
(\mathbf{2 0 0 1})\end{array}$ & $\begin{array}{c}0.7 \\
(1977)\end{array}$ & $\begin{array}{c}0.0 \\
(1981)\end{array}$ & $\begin{array}{c}3.3 \\
(1983)\end{array}$ & $\begin{array}{c}0.0 \\
(\mathbf{2 0 1 0})\end{array}$ & $\begin{array}{c}2.8 \\
(1985)\end{array}$ & $\begin{array}{c}26.8 \\
(1953)\end{array}$ & $\begin{array}{c}28.2 \\
(1950)\end{array}$ & $\begin{array}{c}18.7 \\
(1983)\end{array}$ & $\begin{array}{c}58.7 \\
(1985 / 86)\end{array}$ & \begin{tabular}{|c|}
276.5 \\
$(1983)$ \\
\end{tabular} \\
\hline & wettest & $\begin{array}{l}189.3 \\
(1974) \\
\end{array}$ & $\begin{array}{l}261.9 \\
(1982)\end{array}$ & $\begin{array}{l}189.0 \\
(1976) \\
\end{array}$ & $\begin{array}{l}147.6 \\
(\mathbf{2 0 0 4}) \\
\end{array}$ & $\begin{array}{l}139.5 \\
(1970) \\
\end{array}$ & $\begin{array}{l}157.5 \\
(1953) \\
\end{array}$ & $\begin{array}{c}153.5 \\
(1970) \\
\end{array}$ & $\begin{array}{c}198.4 \\
(1982) \\
\end{array}$ & $\begin{array}{c}264.8 \\
(1959) \\
\end{array}$ & $\begin{array}{l}461.6 \\
(1976) \\
\end{array}$ & $\begin{array}{c}221.7 \\
(1993) \\
\end{array}$ & $\begin{array}{l}300.0 \\
(\mathbf{2 0 0 7})\end{array}$ & $\begin{array}{c}329.3 \\
(1976) \\
\end{array}$ & $\begin{array}{c}340.0 \\
(1969) \\
\end{array}$ & $\begin{array}{l}564.5 \\
(1976) \\
\end{array}$ & $\begin{array}{c}421.7 \\
(\mathbf{2 0 1 0 / 1 1}) \\
\end{array}$ & \begin{tabular}{|l|}
1246.4 \\
$(1976)$ \\
\end{tabular} \\
\hline \multirow{2}{*}{$\begin{array}{c}\text { Tasiilaq } \\
\text { (Jan 1898-present) }\end{array}$} & driest & $\begin{array}{c}4.8 \\
(1948) \\
\end{array}$ & $\begin{array}{c}1.9 \\
(1957) \\
\end{array}$ & $\begin{array}{c}11.8 \\
(1940) \\
\end{array}$ & $\begin{array}{c}2.0 \\
(1950) \\
\end{array}$ & $\begin{array}{c}2.2 \\
(1941) \\
\end{array}$ & $\begin{array}{c}0.0 \\
(\mathbf{2 0 1 2}) \\
\end{array}$ & $\begin{array}{c}0.3 \\
(1954) \\
\end{array}$ & $\begin{array}{c}1.0 \\
(1943) \\
\end{array}$ & $\begin{array}{c}3.4 \\
(1948) \\
\end{array}$ & $\begin{array}{c}16.2 \\
(1935) \\
\end{array}$ & $\begin{array}{c}13.7 \\
(\mathbf{2 0 1 0}) \\
\end{array}$ & $\begin{array}{c}5.0 \\
(1930) \\
\end{array}$ & $\begin{array}{r}122.9 \\
(1915) \\
\end{array}$ & $\begin{array}{c}37.9 \\
(1924) \\
\end{array}$ & $\begin{array}{l}111.5 \\
(1935) \\
\end{array}$ & $\begin{array}{c}38.5 \\
(1930 / 31) \\
\end{array}$ & $\begin{array}{c}612.9 \\
(1950) \\
\end{array}$ \\
\hline & wettest & $\begin{array}{c}565.1 \\
(1972) \\
\end{array}$ & $\begin{array}{l}594.9 \\
(1932) \\
\end{array}$ & $\begin{array}{c}552.3 \\
(1964) \\
\end{array}$ & $\begin{array}{c}258.9 \\
(1909) \\
\end{array}$ & $\begin{array}{c}339.3 \\
(1903) \\
\end{array}$ & $\begin{array}{c}194.5 \\
(1953) \\
\end{array}$ & $\begin{array}{c}251.1 \\
(1901) \\
\end{array}$ & $\begin{array}{l}300.6 \\
(1947) \\
\end{array}$ & $\begin{array}{c}342.3 \\
(1996) \\
\end{array}$ & $\begin{array}{c}687.9 \\
(1914) \\
\end{array}$ & $\begin{array}{c}409.7 \\
(1902) \\
\end{array}$ & $\begin{array}{c}383.0 \\
(1970) \\
\end{array}$ & $\begin{array}{l}693.0 \\
(1964) \\
\end{array}$ & $\begin{array}{l}534.8 \\
(1901) \\
\end{array}$ & $\begin{array}{l}1073.8 \\
(1902) \\
\end{array}$ & $\begin{array}{c}1035.5 \\
(1971 / 72) \\
\end{array}$ & $\begin{array}{l}2165.1 \\
(1908) \\
\end{array}$ \\
\hline \multirow{2}{*}{$\begin{array}{c}\text { Ikerasassuaq } \\
\text { (Jan 1958-present, } \\
\text { minus 1981-1992) }\end{array}$} & driest & $\begin{array}{c}43.9 \\
(1993) \\
\end{array}$ & $\begin{array}{c}8.4 \\
(1960) \\
\end{array}$ & $\begin{array}{c}9.1 \\
(\mathbf{2 0 0 1})\end{array}$ & $\begin{array}{c}33.7 \\
(1996) \\
\end{array}$ & $\begin{array}{c}18.3 \\
(1993) \\
\end{array}$ & $\begin{array}{c}10.5 \\
(\mathbf{2 0 1 2})\end{array}$ & $\begin{array}{c}30.3 \\
(\mathbf{2 0 0 0}) \\
\end{array}$ & $\begin{array}{c}25.6 \\
(1997) \\
\end{array}$ & $\begin{array}{c}72.3 \\
(1999) \\
\end{array}$ & $\begin{array}{c}33.4 \\
(\mathbf{2 0 0 4})\end{array}$ & $\begin{array}{c}58.6 \\
(\mathbf{2 0 1 0}) \\
\end{array}$ & $\begin{array}{c}68.1 \\
(\mathbf{2 0 0 7})\end{array}$ & $\begin{array}{c}173.7 \\
(1993) \\
\end{array}$ & $\begin{array}{l}223.3 \\
(\mathbf{2 0 0 0}) \\
\end{array}$ & $\begin{array}{c}396.8 \\
(1980) \\
\end{array}$ & $\begin{array}{c}216.2 \\
(1994) \\
\end{array}$ & \begin{tabular}{|l|}
1588.5 \\
$(1994)$ \\
\end{tabular} \\
\hline & wettest & $\begin{array}{c}747.4 \\
(1961) \\
\end{array}$ & $\begin{array}{c}682.9 \\
(1965) \\
\end{array}$ & $\begin{array}{c}578.7 \\
(1974)\end{array}$ & $\begin{array}{c}658.3 \\
(1976) \\
\end{array}$ & $\begin{array}{l}769.5 \\
(\mathbf{2 0 1 0}) \\
\end{array}$ & $\begin{array}{l}671.4 \\
(\mathbf{2 0 0 5}) \\
\end{array}$ & $\begin{array}{l}475.5 \\
(1977) \\
\end{array}$ & $\begin{array}{c}837.7 \\
(1960) \\
\end{array}$ & $\begin{array}{c}746.7 \\
(1958) \\
\end{array}$ & $\begin{array}{c}897.4 \\
(1960) \\
\end{array}$ & $\begin{array}{c}698.8 \\
(1965) \\
\end{array}$ & $\begin{array}{c}670.5 \\
(1976) \\
\end{array}$ & $\begin{array}{l}1391.7 \\
(1975) \\
\end{array}$ & $\begin{array}{l}1179.4 \\
(1960) \\
\end{array}$ & $\begin{array}{l}1635.2 \\
(1964)\end{array}$ & $\begin{array}{l}1876.0 \\
(1976) \\
\end{array}$ & $\begin{array}{l}4848.1 \\
(1965)\end{array}$ \\
\hline
\end{tabular}


Table 8: Yearly driest and wettest ice core estimated precipitation sums ( $\mathrm{mm}$ w.e. $\left.\mathrm{yr}^{-1}\right)$. The year of occurrence is shown in brackets.

\begin{tabular}{|c|c|c|c|c|c|c|c|c|c|c|c|c|c|c|c|}
\hline Year & HumbMain & Nasau & GITS & D1 & D2 & D3 & D4 & D5 & NEEM-2008-S3 & McBales & Act $2 d$ & Act 3 & $\begin{array}{c}\text { Summit } \\
2010\end{array}$ & $\begin{array}{c}\text { TUNU } \\
2013 \\
\end{array}$ & Act $11 d$ \\
\hline Driest & $\begin{array}{c}82 \\
(1901)\end{array}$ & $\begin{array}{c}193 \\
(1904)\end{array}$ & $\begin{array}{c}199 \\
(1910)\end{array}$ & $\begin{array}{c}492 \\
(1893)\end{array}$ & $\begin{array}{c}301 \\
(1984)\end{array}$ & $\begin{array}{c}278 \\
(1904)\end{array}$ & $\begin{array}{c}283 \\
(1989)\end{array}$ & $\begin{array}{c}220 \\
(1974)\end{array}$ & $\begin{array}{c}129 \\
(1896)\end{array}$ & $\begin{array}{c}121 \\
(1902)\end{array}$ & $\begin{array}{c}243 \\
(1997)\end{array}$ & $\begin{array}{c}471 \\
(1931)\end{array}$ & $\begin{array}{c}156 \\
(1904)\end{array}$ & $\begin{array}{c}83 \\
(1905)\end{array}$ & $\begin{array}{c}237 \\
(1909)\end{array}$ \\
\hline Wettest & $\begin{array}{c}282 \\
(1905)\end{array}$ & $\begin{array}{c}572 \\
(1915)\end{array}$ & $\begin{array}{c}876 \\
(1953)\end{array}$ & $\begin{array}{c}1,404 \\
(1894)\end{array}$ & $\begin{array}{c}724 \\
(1916)\end{array}$ & $\begin{array}{c}679 \\
(1911)\end{array}$ & $\begin{array}{c}747 \\
(1932)\end{array}$ & $\begin{array}{c}608 \\
(1996)\end{array}$ & $\begin{array}{c}368 \\
(1912)\end{array}$ & $\begin{array}{c}357 \\
(1905)\end{array}$ & $\begin{array}{c}645 \\
(1994)\end{array}$ & $\begin{array}{c}1,121 \\
(1972)\end{array}$ & $\begin{array}{c}352 \\
(1916)\end{array}$ & $\begin{array}{c}220 \\
(1940)\end{array}$ & $\begin{array}{c}597 \\
(1995)\end{array}$ \\
\hline
\end{tabular}

